\title{
НОВЫЕ МАТЕРИАЛЫ ДРЕВНЕГО АРХЕОЛОГИЧЕСКОГО КОМПЛЕКСА КАРГАЛИНСКОГО ИСТОРИКО-ГЕОГРАФИЧЕСКОГО МИКРОРАЙОНА*
}

\author{
(C) 2021 г. Горячев Александр Анатольевич1, \\ Сараев Владимир Васильевич ${ }^{1}$, \\ Егорова Татьяна Александровна ${ }^{1}$, Чернов Михаил Алексеевич ${ }^{1}$
}

${ }^{1}$ автор-корреспондент, старший научный сотрудник,

Институт археологии им. А.Х. Маргулана,

г. Алматы, Казахстан. E-mail: aga.2805@mail.ru

${ }^{1}$ специалист естественных наук, Институт археологии им. А.Х. Маргулана,

г. Алматы, Казахстан. E-mail: saraev.53@mail.ru

${ }^{1}$ специалист-филолог, Институт археологии им. А.Х. Маргулана,

г. Алматы, Казахстан. E-mail: ega.0108@mail.ru

${ }^{1}$ специалист-художник, Институт археологии им. А.Х. Маргулана,

г. Алматы, Казахстан. E-mail: mihalapych@yandex.kz

Аннотация. В статье систематизированы материалы древних археологических памятников Каргалинского историко-географического микрорайона (водный бассейн p. Узын-Каргалы) северных склонов Заилийского/Иле Алатау. Как правило, поселения древних земледельцев располагались в устье, на выходе горных ущелий и предгорной равнине. В бронзовом веке они устраивались близ головных водозаборов каналов и арыков. В раннем железном веке они строили оросительные системы на расстоянии до 20 км от гор, применяя акведуки. Скотоводы раннего железного века осваивали горные ущелья и плато микрорайона как под сезонные стоянки, так и под стационарные поселения. Древние погребальные памятники расположены в основном на возвышенностях у выходов из горных ущелий. В горной зоне они сконцентрированы на склонах горной гряды Майтобе и по левому берегу реки Узын-Каргалы в районе ущелья Жылысай.

Наиболее ярким памятником региона считается каргалинское захоронение раннего железного века, где в 1939 г. обнаружен известный «Каргалинский клад», местоположение которого до сих пор оставалось неясным. По итогам исследований оно определено в 500 м вглубь от входа ущелья Ерменсай под объектом, условно называемым «Каргалинский камень - Каратас». Уникальный погребальный комплекс представляет собой массивный скальный блок, который использовался как монументальная надмогильная конструкция. Зафиксированный вещевой материал позволяет идентифицировать его как место известного каргалинского захоронения. Данный факт позволяет представить необычную традицию погребальной практики населения региона усуньского периода раннего железного века.

Ключевые слова: археология, «Каргалинский клад», поселение, могильник, погребальный инвентарь

*Работа выполнена при финансовой поддержке Комитета науки МОН РК, программно-целевое финансирование на 2021-2022 гг. 


\title{
КАРҒАЛЫ ТАРИХИ-ГЕОГРАФИЯЛЫК ШАҒЫН АУДАНЫНЫН ЕЖЕЛГІ АРХЕОЛОГИЯЛЫК КЕШЕНІНЕН ТАБЫЛҒАН ЖАНА МАТЕРИАЛДАР
}

\section{Горячев Александр Анатольевич ${ }^{1}$, Сараев Владимир Васильевич ${ }^{1}$, Егорова Татьяна Александровна ${ }^{1}$, Чернов Михаил Алексеевич ${ }^{1}$}

\author{
${ }^{1}$ корреспондент авторы, аға ғылыми қызметкер, Ә.Х. Марғұлан атындағы \\ Археология институты, Алматы қ., Қазақстан. E-mail: aga.2805@mail.ru \\ ${ }^{1}$ жаратылыстану ғылымдарының маманы, Ә.Х. Марғұлан атындағы \\ Археология институты, Алматы қ., Қазақстан. E-mail: saraev.53@mail.ru \\ ${ }^{1}$ филолог-маманы, Ә.Х. Марғұлан атындағы Археология институты, \\ Алматы қ., Қазақстан. E-mail: ega.0108@mail.ru \\ ${ }^{1}$ суретші-маманы, Ә.Х. Марғұлан атындағы Археология институты, \\ Алматы қ., Қазақстан. E-mail: mihalapych@yandex.kz
}

\begin{abstract}
Аннотация. Мақалада Іле Алатауының солтүстік баурайындағы Қарғалы тарихи-географиялық шағын ауданының (Ұзын Қарғалы өзенінің су алабы) ежелгі археологиялық ескерткіштерінің материалдары жүйеленген. Әдетте, ежелгі жер өңдеушілер қоныстары тау шатқалдарына кіре берісте және шығысында, сондай-ақ тау бөктеріндегі жазықта орналасатын болған. Олар қола дәуірінде негізгі су жиналатын ирригациялық тоғандардың, яғни, каналдар мен арықтардың жанында орналасқан. Ерте темір дәуірінде жер өңдеушілер көпір түріндегі өтпелерді пайдалану арқылы, тау бөктерінен 20 шақырым қашықтықта суландыру жүйелерін салды. Ерте темір дәуірінің малшылары тау шатқалдары мен шағын ауданның үстірттерін маусымдық тұрақтар үшін де, тұрақты қоныстар үшін де белсенді түрде игерген. Ежелгі жерлеу ескерткіштері -қорғандар мен қоршаулар негізінен тау шатқалдарынан шыға берістегі төбелерде орналасқан. Таулы аймақта олар Майтөбе тау жотасының баурайында және Жылысай шатқалы ауданындағы Ұзын-Қарғалы өзенінің сол жағалауында шоғырланған.

1939 ж. белгілі «Қарғалы көмбесі» табылған және нақты орналасқан жері әлі күнге дейін анық емес Қарғалы ерте темір дәуірі жерлеу кешені - өңірдің ең жарқын жерлеу кешені болып саналады. Зерттеу нәтижелері бойынша ол кіреберістен 500 м ішкерлей, Ерменсай бүйір шатқалында, шартты түрде «Қарғалы тас - Қаратас» деп аталатын нысанда анықталды. Бірегей жерлеу кешені монументалды қабір үсті құрылымы ретінде пайдаланылған ірі жартасты блок болып табылады. Айылбастар және тіліктер секілді табылған киім-кешек материалдары бұл жерлеу орнын атақты Қарғалы жерлеу орнымен сәйкестендіруге мүмкіндік береді. Бұл мәлімет аймақ тұрғындарының ерте темір дәуірінің үйсін кезеңі жерлеу практикасының ерекше дәстүрін ұсынуға мүмкіндік береді.
\end{abstract}

Түйін сөздер: археология, «Қарғалы көмбесі», қоныс, бейіт, жерлеу орны

\section{NEW MATERIALS \\ FROM THE ANCIENT ARCHAEOLOGICAL COMPLEX IN KARGALY HISTORICAL GEOGRAPHICAL DISTRICT}

\section{Goryachev Alexander ${ }^{1}$, Saraev Vladimir ${ }^{1}$, Egorova Tatiana $^{1}$, Chernov Mikhail ${ }^{1}$}

\author{
${ }^{1}$ corresponding author, Senior researcher, A.Kh. Margulan Archeology Institute. \\ Almaty, Kazakhstan. E-mail: aga.2805@mail.ru \\ ${ }^{1}$ Scientific of natural sciences, A.Kh. Margulan Archeology Institute. \\ Almaty, Kazakhstan. E-mail: saraev.53@mail.ru \\ ${ }^{1}$ Specialist philologist, A.Kh. Margulan Archeology Institute, \\ Almaty, Kazakhstan; E-mail: ega.0108@mail.ru \\ Specialist draftsman, A.Kh. Margulan Archeology Institute. \\ Almaty, Kazakhstan. E-mail: mihalapych@yandex.kz
}


Abstract. In the article, the materials of ancient archaeological monuments of Kargaly historical and geographical district (water basin of the Uzyn-Kargaly River) of the northern slopes of Ile Alatau are systematized. As a rule, the settlements of ancient farmers were located at the mouth and at the outlet of mountain gorges, as well as on the foothill plain. In the Bronze Age, they were located near the headwater intakes of canals and ditches. In the Early Iron Age, farmers built irrigation systems at a distance of up to $20 \mathrm{~km}$ from the mountain slopes, using such types of structures as aqueducts. Early Iron Age cattlemen actively developed mountain gorges and plateaus, both for seasonal camps and for stationary settlements. Ancient burial monuments are located mainly on the uplands at the exits from the mountain gorges. In the mountain zone, they are concentrated on the slopes of the Maitobe mountain range and on the left bank of the Uzyn-Kargaly River in the area of Zhylysay canyon.

Kargaly burial site of the Early Iron Age is justly considered the most striking burial complex of the region, where the famous "Kargaly treasure" was discovered in 1939, its location remained unclear until now. According to the results of the research, it was determined $500 \mathrm{~m}$ deep from the entrance of the Ermensay gorge under the object conventionally called "Kargaly stone - Karatas". The unique burial complex is a massive rock block, which was used as a monumental gravestone structure. Recorded material (plaques and plates) allow to identify it as a place of known Kargaly burial. This fact allows us to present an unusual tradition of the burial practice of the population of the region of the Wusun period of the Early Iron Age. equipment

Keywords: archaeology, "Kargaly treasure", settlement, burial ground, burial

\section{Введение}

Наиболее значительную часть Северного Притяньшанья составляет историко-географический регион Жетысу, занимающий юго-восточную часть Казахстана. Он связан транзитными маршрутами через северные склоны Иле Алатау с Иссык-Кульским котлованом, через Чуйскую/Шускую долину - со Средней Азией. Самые крупные реки хребта берут свое начало среди его снежных вершин и ледников и являлись основой для жизнедеятельности людей в историческом прошлом. Древние комплексы бронзового и раннего железного века, состоящие из поселений и могильников, фиксируются на выходе практически из каждого ущелья по северным склонам Иле Алатау. Они обычно устраивались на высоких надпойменных террасах лессовых отложений. Поселения состоят из нескольких (до 10-12) усадеб, концентрирующихся у

небольших естественных водоемов и чаще всего вытянутых вдоль береговой линии крупных рек [Горячев, Сараев, 2015, с. 5-18; 2017, с. 127-136]. Одним из наиболее насыщенных археологическими памятниками на данной территории регионов является Каргалинский историко-географический микрорайон, представляющий собой водный бассейн реки Узын-Каргалы.

Он расположен близ западной оконечности гор Иле Алатау, являющихся частью горной системы Северного Тянь-Шаня (рис. 1). Западнее высота хребта резко понижается вплоть до Киндыктасских возвышенностей. Ущелье Узын-Каргалы граничит с урочищами Улькенсаз и Майбулак на западе, с ущельем Кайнар и урочищем Ушконыр на востоке. В верховьях хребет начинает превышать отметку 2400 м над у.м., здесь же на северных склонах имеются небольшие ледники, 


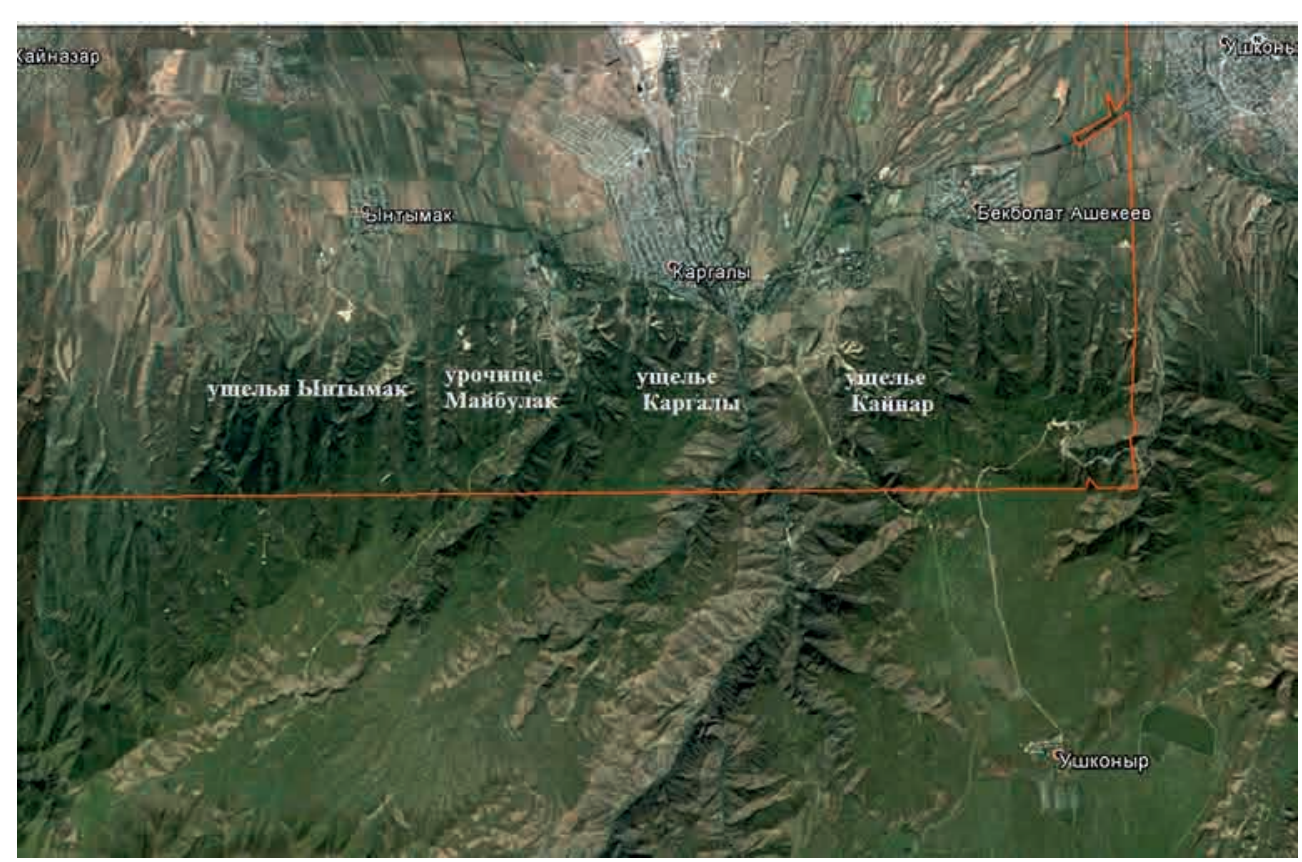

Рис. 1. Территория Каргалинского историко-географического микрорайона северных склонов Иле Алатау на космоснимке

Fig. 1. Territory of Kargaly historical and geographical district of the northern slopes of Ile Alatau on the satellite image

которые инициируют основные истоки реки Узын-Каргалы - Каргалы, Майбулак, Егарджан, Сарысай и Алеяк. Протяженность водной поверхности микрорайона составляет более 100 км. Структурно к этим водным источникам принадлежит серия родниковых ручьев Кайнар, Майбулак и в районе села Ынтымак. В самом ущелье в ее пойме произрастает тугайный лес с зарослями облепихи, шиповника, боярышника и барбариса. Оно ориентировано в общем направлении по оси Ю3-СВ. Расположенные в ущельях и в поймах рек поселения и могильники составляют единый комплекс археологических памятников эпохи бронзы и раннего железа данного микрорайона.

Значение Каргалинского историко-географического региона (Жамбылский р-н, Алматинская обл.) представляется наличием археоло- гических комплексов всех этапов развития человечества от палеолита до современности, характеризующих историко-культурные процессы предгорной и горной зоны Северного Притяньшанья. Производственная деятельность древнего населения связана с развитием на данной территории комплексного скотоводческоземледельческого хозяйства. Жители горной зоны занимались исключительно скотоводством, а в предгорных равнинах фиксируются многочисленные следы крупных стационарных поселков земледельцев [Сараев, 2017, c. 78].

Археологические изыскания в предгорной зоне микрорайона начались ещё в 1930-е гг. А.Н. Бернштамом [Бернштам, 1952]. Им были обследованы древние курганы в окрестностях пос. Фабричный (ныне Каргалы), а также впервые опубликованы матери- 
алы Каргалинского клада [Бернштам, 1940, с. 23-31]. В 1970-1990-е гг. здесь периодически сотрудниками Института «Казпроектреставрация»»», ЦГМ РК, КазГУ им. аль-Фараби и Института археологии им. А.Х. Маргулана изучались аварийные памятники эпохи бронзы и раннего железа [Caраев, 1992, с. 104-109; Сараев, Первых, 2001, с. 165-170; Мотов, 2007, c. 80-87; Нурмуханбетов, Трифонов, 2016 , с. 10-18]. В начале XXI в. в рамках программы «Культурное наследие» часть памятников предгорной зоны микрорайона (преимущественно курганы раннего железного века) была систематизирована и включена в «Свод памятников истории и культуры Алматинской области» [Свод..., 2009; Горячев, Сараев, Потапов, 2016].

Горная часть водного бассейна реки Узын-Каргалы оставалась неисследованной (за исключением разведок, проводимых В.В. Сараевым в частном порядке). В 2020 г. археологическая разведка этой части древнего микрорайона затронула горные плато левого берега р. Узын-Каргалы, где обследованы северные и южные склоны горы Майтобе, урочища Майбулак, Улькенсаз, Бутасаз, ущелья Жылысай и Ерменсай (прежнее название последнего: Мынг-Ошакты-прим. авт.), охватила русло реки и прилегающие к нему горные ущелья на расстояние до 20 км вглубь от его устья. В результате выявлена система расположения древних поселений и могильников в горной зоне и выяснены особенности хозяйственного освоения микрорайона в древности.

Наиболее ярким археологическим объектом Каргалинского ущелья является так называемый «Каргалинский клад», обнаруженный в 1939 г. группой местных жителей и предва- рительно обследованный археологом Б.Н. Дублицким (о Б.Н. Дублицком см.: [Бейсенов и др., 2017, с. 16-17]). Однако в силу определенных субъективных и объективных причин дальнейшие полевые исследования данного памятника специалистами не проводились. В результате точное местонахождение находки осталось неизвестно никому из специалистов (за исключением А.Н. Бернштама, посетившего памятник в 1940 или 1941 г.) [Бернштам, 1940, с. 23-31], а все последующие изыскания касались осмысления комплекса артефактов и, прежде всего, Каргалинской диадемы [Акишев К., Акишев А., 1983; Кузьмина, 1987, с. 158-181; Самашев, Григорьев, Жумабекова, 2005; Культура саков и усуней Казахстана..., 2011; Чернов, 2015, с. 376-384; 2016, c. 110-130; Яценко, 2017, с. 143-155]. Одна из основных задач поисков в 2020 г. состояла в обследовании предполагаемого места расположения этой уникальной находки и определении характера и особенностей данного археологического объекта, так как это имеет важное значение для его характеристики и понимания всего комплекса известных артефактов «Каргалинского клада».

\section{Методика исследований}

Определение структур древних археологических комплексов Каргалинского историко-географического микрорайона производилось на основе сбора и анализа имеющихся архивных и библиографических материалов, топографических карт и дешифровки космических снимков горных плато левобережья р. Узын-Каргалы (рис. 2). В результате последующего натурного обследования археологи- 


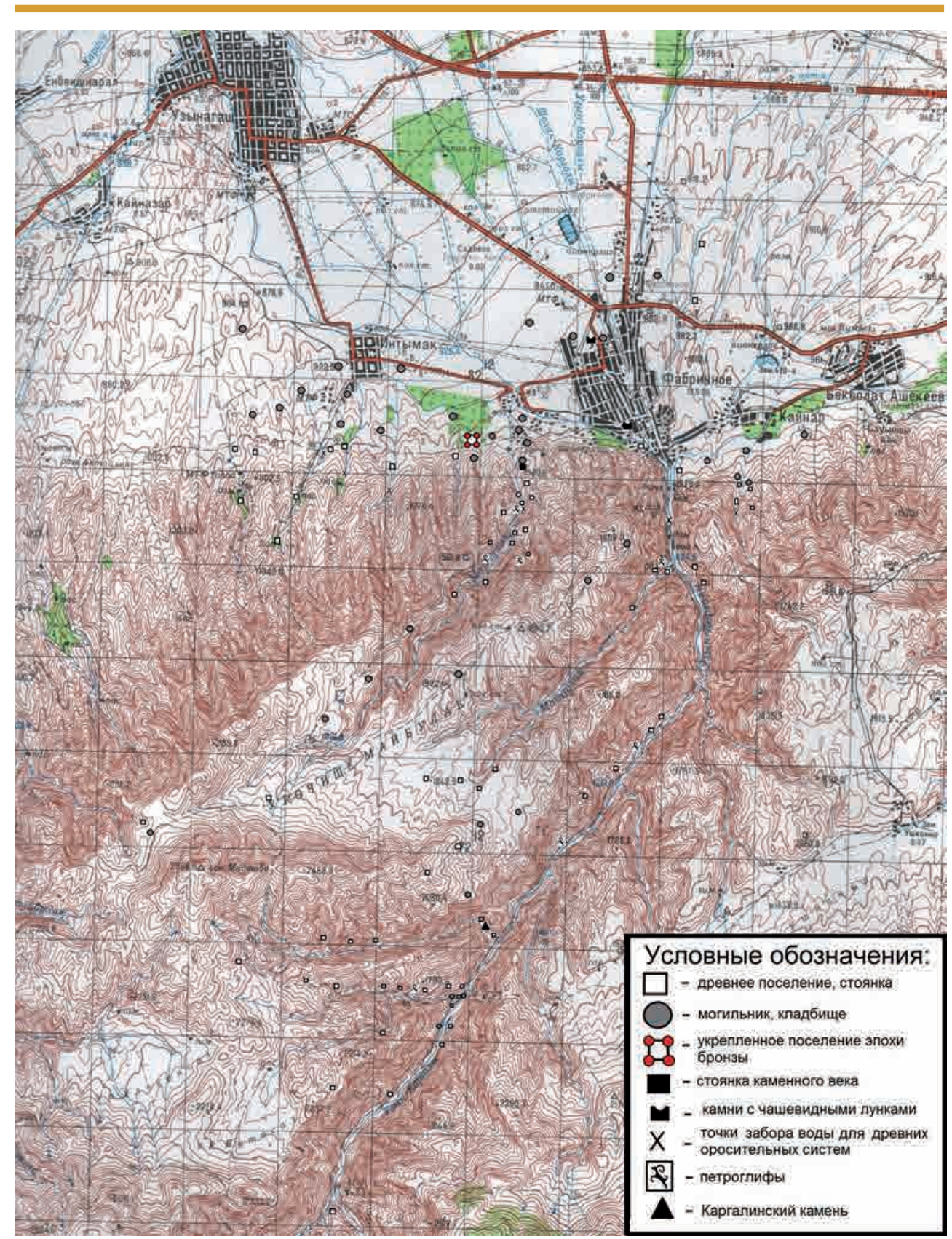

Рис. 2. Карта древних археологических памятников Каргалинского историко-географического микрорайона

Fig. 2. The map of ancient archeological monuments of Kargaly historical and geographical district

ческих объектов получены материалы для дальнейшей систематизации данных по хозяйственно-культурному освоению микрорайона в раннем же- лезном веке. Выявлен и картирован наиболее крупный комплекс древних памятников в районе ущелья Жылысай в долине р. Узын-Каргалы. 
В ущелье Ерменсай зафиксирован особый археологический объект «Каргалинский камень», который в ходе предварительных археологических раскопок был интерпретирован как место обнаружения древнего захоронения, известного как «Каргалинский клад». Памятник обследован, документирован, составлена предварительная графическая реконструкция его первоначального вида. Металлические изделия подвергнуты предварительному анализу технологии их производства и применения. Полученные в ходе работ данные позволяют представить необычную традицию погребальной практики населения региона в раннем железном веке.

Описание материалов разведки Каргалинского ущзелья

Предыдущие исследования в предгорной зоне и устьях горных ущелий микрорайона выявили свыше 80 древних археологических памятников (рис. 2), среди которых были систематизированы материалы палеолитической стоянки Майбулак-V, укрепленного поселения бронзового века Майбулак-II, серии древних и средневековых поселений и стоянок на выходе и в устьях горных ущелий Кайнар, Каргалы, Майбулак и Ынтымак, а также древних могильников, серии «чашечных» камней и ирригационных сооружений (водозаборов, каналов, акведуков и т.д.) [Сараев, 2007, с. 120-128; 2017, с. 78-82; 2017a, с. 69-90; Таймагамбетов, 2008, c. 34-40].

Поселения бронзового века отмечены преимущественно на выходе из ущелий Кайнар, Майбулак и Ынтымак (рис. 3, 1-3). Они представляют собой серии площадок под хозяйственно-жилые подворья.
В них насчитывается от 10-12 до 15-20 жилых сооружений. Жилища устраивались у подножия склонов увалов и представлены полуземлянками квадратной и прямоугольной форм от $5 \times 5$ м до $8 \times 6$ м. Напротив каждого вдоль берега речек и ручьев просматриваются фрагменты каменных ограждений хозяйственных дворов овально-прямоугольных форм от $7 \times 6$ м до $20 \times 10$ м.

Наиболее крупным в регионе является укрепленное поселение Майбулак-II общей площадью свыше

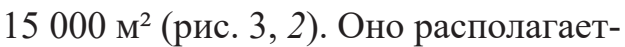
ся на верхней надпойменной террасе левого берега р. Майбулак. Раскопомтраншеей 1987 г. произведена зачистка стенок оврага на протяжении 36 м, в глубину до 3,2 м, на юго-западном участке террасы раскопом площадью $220 \mathrm{M}^{2}$ исследован верхний строительный горизонт. В результате проведенных работ представлена стратиграфия памятника. Выявлено, что поселение на юго-западном и северо-западном участках террасы имело глинобитную оборонительную стену, сооруженную на фундаменте из крупного речного камня. На дне оврага расчищен жертвенник, представляющий собой круглый «стол» диаметром 1,1 м, вырезанный из глины. К поселению подводился арык от одноимённого родника, расположенного в 800 м вглубь ущелья по его левому борту. Материалы контрольных раскопок показывают, что оно функционировало на протяжении всего андроновского и позднебронзового периодов.

Ярким памятником региона на выходе из ущелья Майбулак является комплекс разновременных и разнотипных объектов палеолита-неолита, эпохи бронзы и раннего железа Майбулак-V (рис. 3, 4). Холм - оста- 

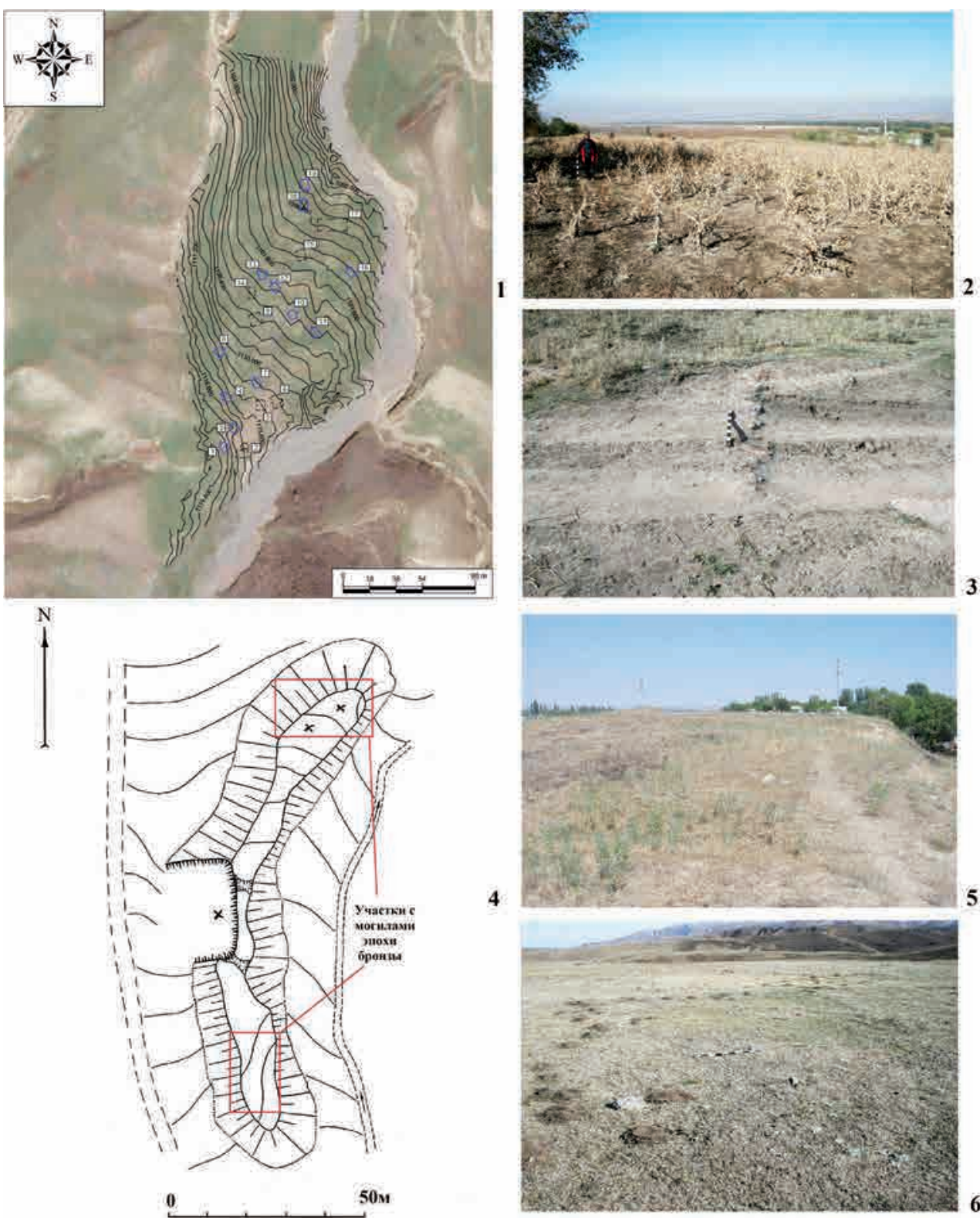

4
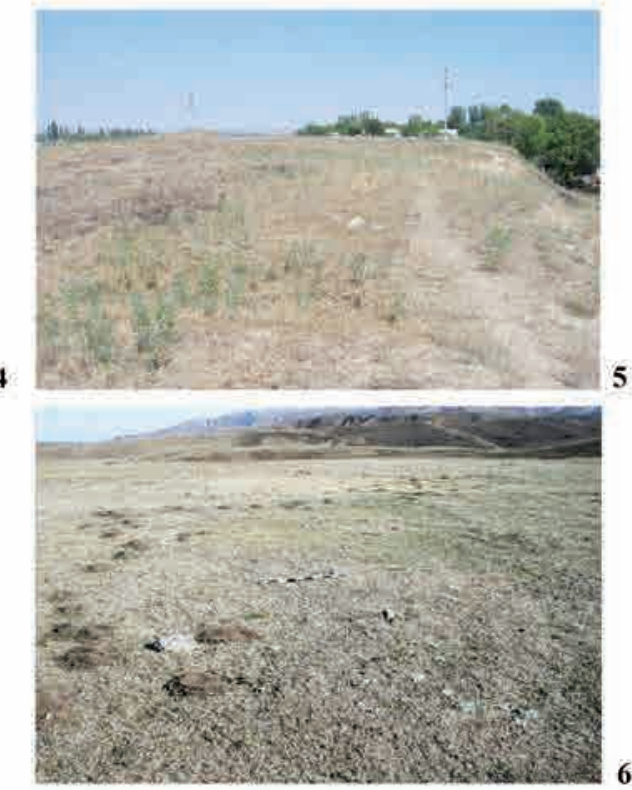

Рис. 3. Памятники эпохи бронзы предгорной зоны Каргалинского микрорайона:

1 -топографический план поселения Кайнар-I (Гурулев М.В);

2 - поселение Майбулак-II, вид на северо-запад; 3 - каменные конструкиии жилища поселения Бнтылмак-I, вид на восток; 4 - план-схема расположения могильника эпохи бронзы на комплексе Майбулак-V; 5 - могильник Каргаль-I, вид на север; 6-могильник Ынтылмак-II, вид на восток (фото 1-Мотов Ю.А.; 2, 3, 5, 6-Горячев А.А.)

Fig. 3. Monuments of the Bronze Age foothill area Kargaly district: 1 - topographic plan of the settlement Kaynar-I (Gurulev M.); 2 - settlement Maibulak-II, north-west view; 3 - stone structures of the dwelling of Yntymak-I, east view; 4 - schematic layout of the burial ground of the Bronze Age at Maibulak-V complex (Motov Yu.);

5 - Kargaly-I cemetery, view to the north; 6 - Yntymak-II cemetery, view to the east (photos 2, 3, 5, 6-Goryachev A.) 
Горячев А.А., Сараев В.В., Егорова Т.А., Чернов М.А. Новые материалы древнего ...

нец правого борта ущелья представляет собой памятник с многослойной стоянкой каменного века. У его северовосточного края выявлен древний, частично исследованный, могильник с разновременными погребениями эпохи бронзы и раннего железа.

Погребальные комплексы бронзового века расположены, как правило, к северу от поселений (рис. 3, 5, 6). Они занимают участки небольших возвышенностей в их южной части (Кайнар-I, Каргалы-I, Ынтымак-I, II). Исключение составляют могильники эпохи бронзы на выходе из ущелья Майбулак (Майбулак-III, V), устроенные к востоку от укрепленного поселения. Погребальные сооружения здесь представлены оградами округлой и квадратной форм от $2 \times 2$ м до $3 \times 3$ м. Могилы, размерами от $1 \times 0,7 \mathrm{M}$ до $1,5 \times 1$ м, в виде грунтовых ям и каменных цист прямоугольной формы, ориентированы по оси Ю3-СВ. Погребальные традиции (конструкции и обряд) и материалы (керамическая посуда и бронзовые изделия) могильников Кайнар-I, Каргалы-I, Майбулак-III и V, где производились археологические исследования, позволяют отнести эту группу объектов к федоровской традиции андроновской культурно-исторической общности эпохи бронзы региона [Мотов, 2007 , с. $80-87]$.

Поселения раннего железного века существенно отличаются от памятников предыдущей эпохи. На выходе из трех ущелий Каргалинского микрорайона сохраняются только три таких памятника (Кайнар-I, Майбулак-I и Ынтымак-I), остальные группируются в устье и в глубине ущелий. В основной своей массе они занимают относительно ровные площадки у крупных скальных блоков или массивов (рис. $4,1-4$ ). Расположение площадок таких стоянок именно у скал обусловлено климатическими условиями региона. Они имеют экспозиции южного направления, в зимнее время подвергаются более интенсивному прогреву солнечными лучами, чем ближайшее окружение. Наличие скальных нагромождений позволяет аккумулировать солнечное тепло, что создает локальный микроклимат с положительными температурами для проживания и содержания скота.

На поверхности иногда просматриваются каменные основания изгородей или стенок жилых и хозяйственных помещений [Сараев, Кожегулова, 2018, с. 28-29]. Обычно на них устраивались одно-два жилища с пристройками. Это дает основание считать их принадлежащими отдельным малосемейным группам древних скотоводов. Почти на каждом скальном выходе рядом с такими поселениями имеются наскальные рисунки раннего железного века, реже эпохи бронзы и средневековья (рис. 4, 5-7).

В отличие от этих стоянок поселения, расположенные на редких удобных для проживания площадках в устье боковых саев на стыке с основным ущельем, состоят из серии 8-10 жилых и хозяйственных помещений. Места для них выбирались с учетом возможных селевых сходов и паводковых аномалий на высоких площадках с южной экспозицией. Как правило, жилища врезались в склоны по берегу ручья, а по их контуру четко просматриваются каменные выкладки. Это были небольшие однокомнатные помещения размерами от $4 \times 4$ м до $7 \times 5$ м. Выяснить время существования стоянок и поселений в ущелье Узын-Каргалы позволили рекогносцировочные раскопки на стоянке 


\section{ҚАЗАҚСТАН АРХЕОЛОГИЯСЫ № 2 (12) 2021}
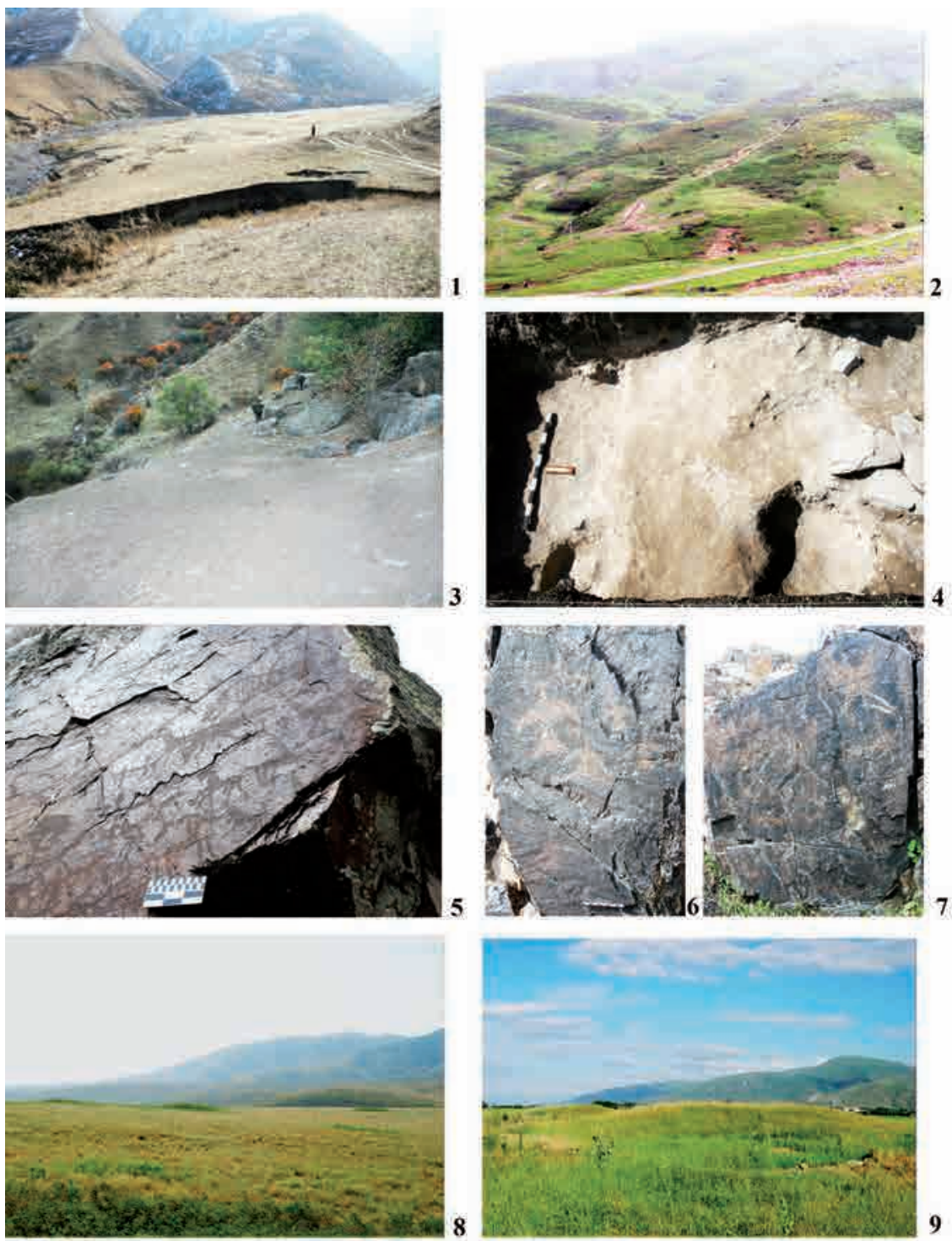

Рис. 4. Памятники раннего железного века предгорной зоны Каргалинского микрорайона:

1 - территория поселения Кайнар-I, вид на юг; 2 - поселение Майбулак-IX,

вид на юго-восток; 3 - площадка поселения Кайнар Б в ущелье Узын-Каргалы,

вид на запад; 4 - контрольный шурф до слоя жилища раннего железного века поселения Кайнар Б, вид на запад; 5 - фрагмент композичии со сиеной охоты тигра близ поселения

в урочище Майбулак; 6, 7 - сиены с изображением птии и верблюда на скалах близ поселения в ущелье Узын-Каргальі; 8 - курганный могильник на выходе из ущелья Кайнар;

9 - курганный могильник на выходе из ущелья Майбулак (фото 1-4 - Горячев А.А.; 5-7-Сараев В.В.; 8, 9 - Мотов Ю.А.)

Fig. 4. Monuments of the Early Iron Age in the foothill area of the Kargaly microdistrict: 1 - the territory of the settlement Kaynar-I, view to the south; 2 - settlement Maybulak-IX, view to the south-east; 3 - site of the settlement Kaynar B in the Uzyn-Kargaly gorge, view to the west; 4 - control pit to the dwelling layer of the Early Iron Age of the settlement Kaynar B,

view to the west; 5 - a fragment of the composition with a tiger hunting scene near the settlement in the Maibulak tract; 6, 7 -scenes with birds and a camel on the rocks near the Uzyn-Kargaly gorge settlement; 8-burial mound at the exit from the Kaynar gorge;

9-burial mound at the exit from the Maibulak gorge (photos 1-4-Goryachev A.; 5-7-Saraev V.; 8, 9-Motov Yu.) 
Горячев А.А., Сараев В.В., Егорова Т.А., Чернов М.А. Новые материалы древнего ...

Кайнар Б (рис. 4, 3, 4). Исследования показали, что оно возникло в позднесакский период как стоянка-зимовка древних скотоводов [Сараев, 2017а, с. 71].

Погребальные памятники этого времени расположены исключительно на выходе из горных ущелий, чаще всего на вершинах широких увалов у подножия горной гряды (рис. 4, 8, 9). Обычно они состоят из цепочек курганов раннего железного века с земляными насыпями полусферической формы и кольцевыми каменными выкладками по периметру. Такие могильники насчитывают от трех до трех десятков погребальных сооружений. Наиболее крупные комплексы являются продолжением могильников бронзового века (Кайнар-I, Каргалы-I, Майбулак-III, Ынтымак-I, II) и по своим внешним параметрам сопоставимы с курганами сакского времени [Ильдеряков, Ярыгин, 2020, с. 63, рис. 1; Нуржанов, Джумабекова, Базарбаева, 2020 , с. 74-75, рис. 2-4].

Насыпи курганов раннего железного века насчитывают в диаметре от 3-4 до 25-30 м. Отмечены захоронения в могилах с подбоем или катакомбах. Обычно погребальная камера овальная, размером $2,3 \times 1$ м, глубиной до 1 м, вытянута по линии В-3. Умерших хоронили на спине, вытянуто, головой на запад. За головой устанавливалась посуда и вещевой материал (нож, пряслице). Среди костей погребенных отмечены многочисленные украшения (подвески, бляшки, бусы и т. д.). В захоронении кургана на могильнике Каргалы-I (диаметр - 18 м) обнаружен крупный керамический котел с двумя ручками. Исследованные курганы микрорайона позволяют предполагать их создание как в сакский период, так и в начале н.э. [Сараев, 2017a, с. 74-75].
В высокогорной зоне по левому берегу реки Узын-Каргалы узловой точкой, по периметру которой формировались древние археологические комплексы, являлась горная гряда Майтобе. Практически со всех ее сторон, кроме обрывистой западной, у ее подножия найдены древние поселения, характерные по структуре для семейно-родовых стоянок скотоводов раннего железного века (рис. 2). С южной стороны Майтобе они расположены в устьях горных саев, выходящих в ущелье Ерменсай, непосредственно до русла р. Узын-Каргалы. Два крупных поселения, насчитывающие 8-10 подворий, отмечены на восточном плече гряды в ущелье Акбастау (рис. 5, 1). Основная часть жилых конструкций представляла собой полуземлянки прямоугольной формы размерами от $5 \times 4$ м до $8 \times 6$ м, для хозяйственных - от $4 \times 3$ м до $5 \times 5$ м. Близ территории стоянок и поселений обнаружены серии сеноставов диаметром 6-8 м, что свидетельствует о вероятности их круглогодичного использования. Во всех случаях поселения и стоянки были устроены у родников горы Майтобе.

Погребальные комплексы раннего железного века отдельными курганами или группами до 3-4 насыпей устроены на вершинах небольших увалов или по бортам отдельных горных ущелий. Они представляют собой каменно-земляные сооружения округлой формы диаметром от 5-6 до 12 м, лишь в урочище Акбастау по северному борту ущелья Ерменсай обнаружены курганные насыпи диаметром до 20 м (рис. 5, 2).

Непосредственно на территории высокогорных плато Улькенсаз и Болексаз к югу от горы Майтобе археологических объектов зафиксировано не было, вероятно, в силу того, что эти участки горной зоны использовались 

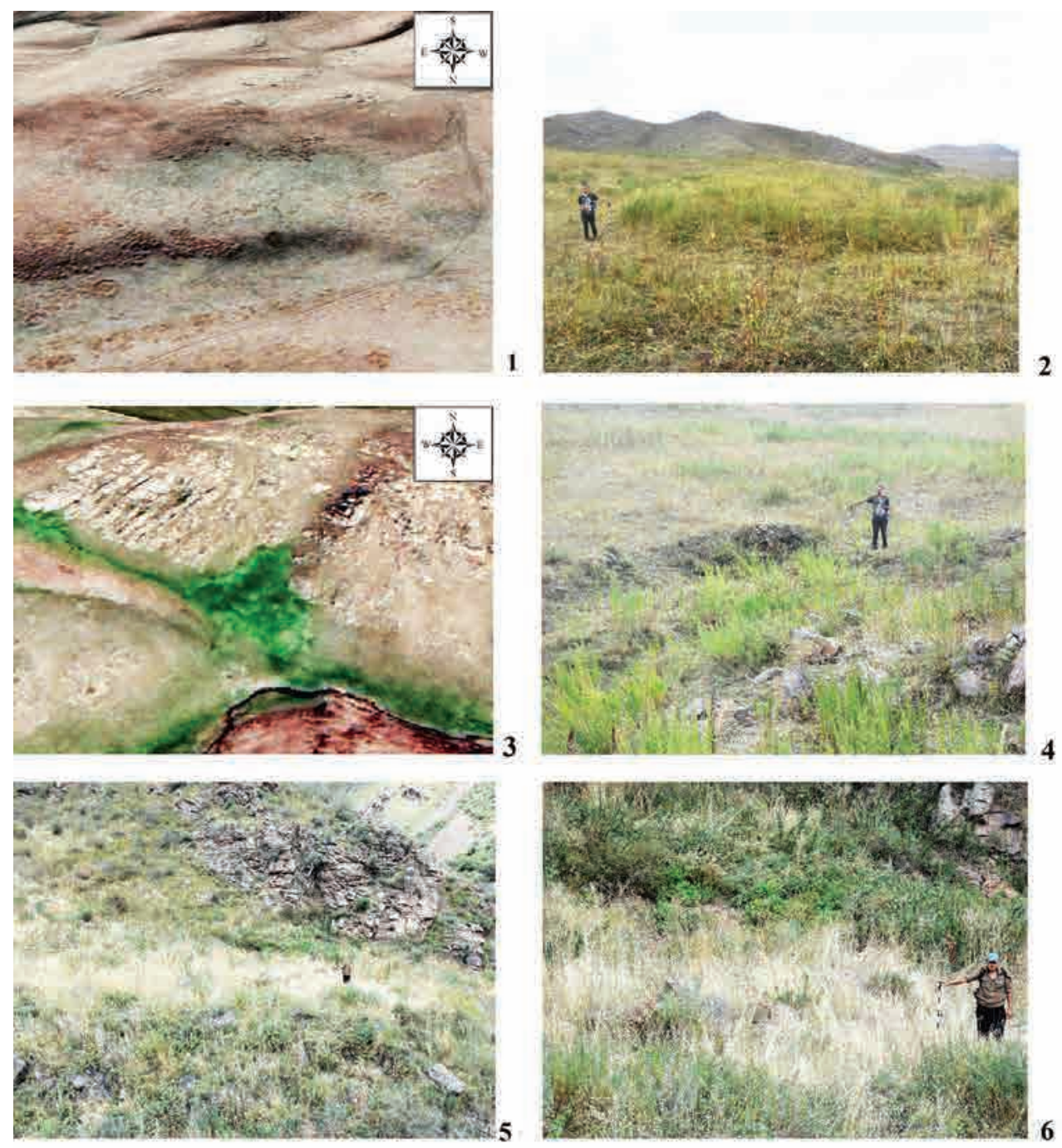

Рис. 5. Памятники раннего железного века горной зоны Каргалинского микрорайона:

1 - поселение Акбастау-I на космоснимке; 2 - курган по северному борту

ущелья Ерменсай, вид на северо-запад; 3 - поселение в горной гряде по левому борту долины р. Узын-Каргальи на космоснимке; 4 - поселение на южных склонах горы Майтобе, вид на юго-запад; 5, 6-древнее поселение в устье ущелья Ерменсай, вид на север (фото 2, 4-6-Егорова T.A.)

Fig. 5. Monuments of the Early Iron Age in the mountainous area of the Kargaly microdistrict: 1 - settlement Akbastau-I on the space image; 2 - the mound on the northern side of the Ermensay gorge, a view to the north-west; 3 -settlement in the mountain range on the left side of the valley Uzyn-Kargaly on the space image; 4 -settlement on the southern slopes of Maytobe mountain, looking south-west; 5, 6- the ancient settlement at the mouth of the Ermensay gorge, looking north (photos 2, 4-6-Egorova T.)

в древности исключительно в хозяйственных целях. Но на прилегающих к ним горных грядах и ущельях, выходящих в долину р. Узын-Каргалы, отмечено около 10 древних подворий, по структурной организации и характеру домостроительных традиций преимущественно раннего железного 
Горячев А.А., Сараев В.В., Егорова Т.А., Чернов М.А. Новые материалы древнего ...

века (рис. 5, 3, 4). Древние поселения, стоянки, могильники и петроглифы выявлены в ходе разведки в долине реки Узын-Каргалы от водозаборной плотины до развилки (места соединения основных притоков реки). На выходе из горных саев, где в древности имелись даже небольшие родники, отмечены следы отдельных стоянок, от которых сохранились западины полуземлянок и каменные основания фундаментов жилищ. Такие же стоянки встречаются в срединной части западного борта ущелья Узын-Каргалы. Параметры жилых и хозяйственных строений в них соответствуют описанным ранее семейно-родовым подворьям племен раннего железного века. Рядом с ними отмечены небольшие скопления наскальных рисунков, преимущественно с изображениями животных в традициях «звериного» стиля.

Примечателен хозяйственножилой комплекс у входа в ущелье Ерменсай, расположенный на 12 км вглубь ущелья от поселка Каргалы (14,5 км пешего маршрута вдоль реки). Древняя стоянка размерами $20 \times 20$ м, ориентированная углами по сторонам света, была устроена по левому берегу пересохшего ручья у подножия отдельной скальной гряды (рис. 5, 5, 6). Внутри она разделяется на три отсека. Вход в комплекс располагался с юговосточной стороны и вел в большой коридорообразный отсек размерами $15 \times 4,5$ м, из которого просматриваются входы в два жилых помещения размером $8 \times 6$ м. Коридор шириной 1,5-2 м между стенками жилищ и внешней оградой стоянки охватывал их по всему периметру. Стенки оград и помещений выложены из крупных скальных блоков, вкопанных вертикально, вероятно, представляли собой основание фундамента древнего домостроения. Второе подворье устроено в 50 м к северо-западу на верхней террасе. Оно представляло собой полуземлянку размерами $8 \times 6$ м, ориентированную по оси СВ-Ю3. С северозападной стороны от нее просматривается выровненная площадка хозяйственного двора (6×4 м). Конструкции двора и жилища по периметру обложены крупными скальными валунами.

Наиболее крупный хозяйственно-жилой комплекс раннего железного века отмечен в 1,5 км выше по течению реки в устье ущелья Жылысай. Здесь были устроены два поселения в 100-300 м вглубь и две стоянки на выходе из него. По правому южному берегу одноименного ручья обнаружен могильник, напротив ущелья по берегу р. Узын-Каргалы устроены еще два крупных кургана (рис. 6, 1). Древнее поселение Жылысай-I расположено в устье ущелья на ровной площадке левого берега ручья, размерами

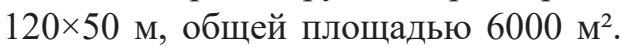
Древние жилые комплексы устроены в три яруса по склону с южной экспозицией. На поверхности просматриваются каменные основания фундаментов жилых конструкций размерами от $6 \times 5$ м до $10 \times 8$ м и хозяйственных дворов округлой (диаметр - 12 м) и подпрямоугольной форм размерами $20 \times 12$ м. Ниже поселения по северному борту ущелья и левому берегу ручья прослеживаются каменные ограждения загонов для скота размерами $15 \times 10(8)$ м (рис. 6,2 , 3). В 150 м вглубь ущелья на скалах отмечена серия петроглифов раннего железного века.

Поселение Жылысай-II расположено на выходе из ущелья по северному борту и занимает участок склона с южной экспозицией между 

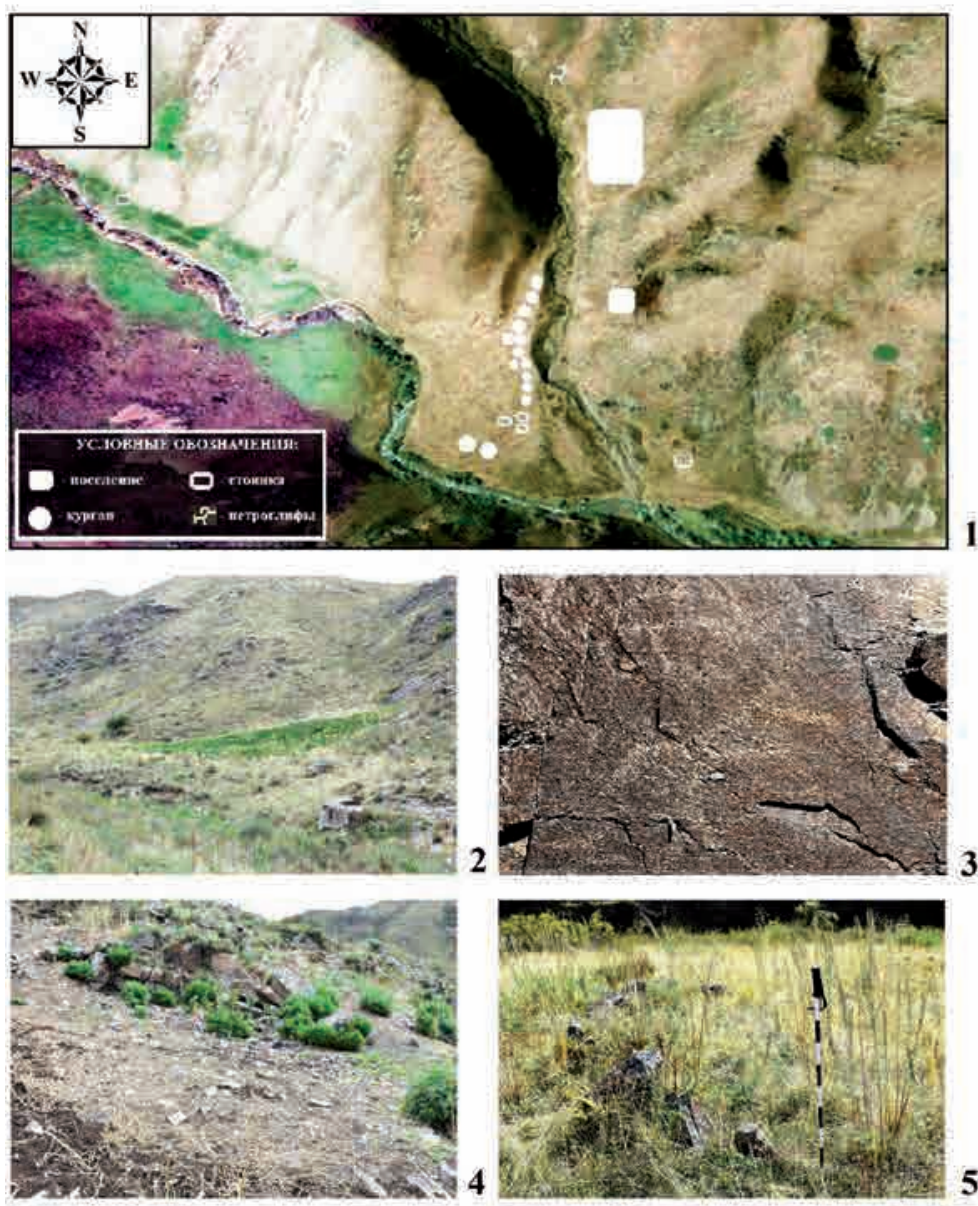

3
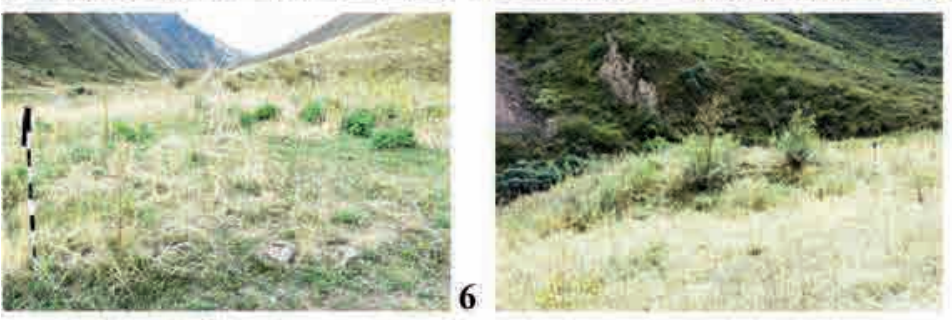

5

Рис. 6. Археологические памятники раннего железного века ущелья Жылысай:

1 - план-схема расположения памятников в устье ущелья Жылысай на космоснимке; 2 - общий вид на северо-запад поселения Жылысай-I; 3 - петроглиф раннего железного века на скале у поселения Жылысай-I; 4 - жилая площадка поселения Жылысай-II, вид на северо-восток; 5 - каменные конструкции жилища стоянки напротив входа в ущелье Жылысай, вид на восток; 6 - курган у входа в ущелье Жыльссай по правому берегу ручья, вид на юг; 7 - курган по левому берегу р. Узын-Каргаль, вид на юго-восток (фото: 2, 4-7-Егорова Т., 3 -Менянбаев Е.)

Fig. 6. Archaeological monuments of the Early Iron Age in the Zhylysay Gorge: 1 - plan-scheme of monuments location in the mouth of Zhylysay gorge on the satellite image; 2 -general view to the north-west of Zhylysay-I settlement; 3 - petroglyph of the Early Iron Age on the rock near

Zhylysay-I settlement; 4 - dwelling site of Zhylysay-II settlement, view to the north-east;

5 - stone structures of the dwelling site opposite the entrance to Zhylysay gorge, view

to the east; 6 - mound at the entrance to Zhylysay gorge on the right bank of the stream, view to the south; 7 - mound on the left bank of the Uzyn-Kargaly river, view to the south-east (photos: 2, 4-7-Egorova T., 3-Menyanbaev E.) 
двух скальных групп. Оно состоит из серии хозяйственных и жилых площадок, устроенных также в три яруса (рис. 6, 4). Контуры каменных конструкций хозяйственно-жилых комплексов занимают центральные площадки ярусов подпрямоугольной формы размерами $15 \times 10 \mathrm{M}, 14 \times 5$ м и $6 \times 3$ м, ориентированные по оси В-3. К востоку от них прослеживаются следы еще четырех полуземлянок размерами $7 \times 5$ м. К северу от жилых конструкций просматриваются конструкция загона для скота и хозяйственный двор общими размерами $15 \times 12$ м. Площадь обоих поселений активно использовалась в хозяйственных целях (сохранился каменный домик 1920-1930-х гг., выполненный в традициях близких к древним).

В 200 м к востоку от них на выходе из ущелья Жылысай с северной стороны у подножия западного борта ущелья Узын-Каргалы найдена небольшая стоянка $(12 \times 8$ м), обнесенная по периметру каменной кладкой. На противоположном берегу ручья, напротив входа в ущелье, расположена еще одна стоянка из двух жилищ юртообразной формы диаметром 7 м. По контуру данные строения были обнесены крупными плитами, вкопанными на ребро (рис. 6, 5). Здесь обнаружены фрагменты керамической посуды, по технологии производства и формам схожие с керамикой раннего железного века, а также, по берегу ручья Жылысай, зафиксирован могильник из 13 (еще два сползли вниз и разрушились) курганов с каменноземляными насыпями диаметром от 2 до 6 м и кольцевыми выкладками по периметру (рис. 6, б). Курганы вытянуты вплоть до устья ущелья в две цепочки, ориентированные в общем направлении В-3. Восточнее стоянки с юртообразными жилищами по левому берегу р. Узын-Каргалы отмечены два крупных кургана (диаметром 15 и 12 м). Насыпи курганов каменноземляные, оплывшие, задернованы, в верхней части уплощены (рис. 6, 7). По периметру насыпей и в 1,5-2,5 м от них прослеживаются кольцевые каменные ограды. Малый северный курган имеет следы современных попыток ограбления.

Выше по течению р. УзынКаргалы, вплоть до развилки, большинство поселений и стоянок сосредоточены по правому восточному борту ущелья, преимущественно на выходе из горных ущелий и саев с родниками. Примечательно, что близ двух таких поселений обнаружен могильник раннего железного века, состоящий из серии курганов, насыпи которых сложены полностью из камней. Параметры таких насыпей варьируют от 5-6 м до 15 м, по их периметру также прослеживается кольцевая каменная ограда. Часть курганов засыпана камнями, насыпь самого крупного частично разобрана по центру.

Описание материалов исследований Каргалинского камня

После обнаружения в 1939 г. так называемого «Каргалинского клада» дальнейшие исследования этого, несомненно, интересного археологического объекта не проводились. В связи с этим, кроме анализа части вещевого материала данного объекта, другие сведения о нем ограничивались предварительным заключением археолога Б.Н. Дублицкого, датированным концом октября того же года [Дублицкий, 1939, с. 24-25], согласно которому место находки располагалось по левому берегу р. Узын-Каргалы в горном ущелье близ урочища Мынг-Ошакты 
в 15 км к юго-западу от Суконного комбината (южная окраина пос. Фабричный). Как в дальнейшем выяснилось, данное заключение изобиловало определенными неточностями и в указании расстояния до объекта (15 км - это расстояние до верховьев ущелья, сама находка оказалась ближе), и в описании погребального комплекса (он объявлен случаем горного обвала, в результате которого погребенный оказался под завалом и был «разграблен» животными). Вероятно, причиной таких преднамеренных неточностей явилось желание автора защитить от возможного уголовного преследования людей, обнаруживших захоронение и сдавших эту находку государству.

В этом же заключении Б.Н. Дублицким высказана идея произвести весной 1940 г. аварийные раскопки подкаменного пространства на глубину 30-50 см. Это свидетельствует о понимании им обнаруженных находок как части погребального комплекса, который необходимо было доследовать. Однако в связи с арестом и осуждением за антисоветскую деятельность воплотить эти планы ему было не суждено. Точных сведений, в каком из ущелий следует искать место Каргалинского захоронения, не сохранилось. В результате за последующие 40 лет обстоятельства находки «обросли» невероятным количеством «шумовой» информации, вплоть до литературных маргиналий, которые полностью исказили как обстоятельства, так и условия обнаружения столь значимого в отечественной истории археологического комплекса.

Одним из авторов настоящей работы (В.В. Сараев) еще в конце 1970-х гг. был начат сбор сведений о Каргалинской находке, который позволил при сопоставлении получен- ных сведений с экспертным заключением Б.Н. Дублицкого и первичным описанием А.Н. Бернштама прийти к выводу, что этот археологический объект мог находиться исключительно в ущелье Ерменсай, ограничивающим хребет Майтобе с юго-восточной стороны (рис. 7, 1). Это действительно труднодоступное, поросшее значительным количеством колючих кустарников ущелье, по бортам которого имеется серия скальных гротов, а на дне несколько крупных валунов, сорвавшихся со склонов. Оно оказалось достаточно обжитым в древности и средневековье: на его территории обнаружено шесть хозяйственножилых подворий, расположенных в основном в его средней и верхней части (рис. 7, 2, 3). Они были привязаны к действующим родникам и ручью Ерменсай. Однако все коммуникации и хозяйственная деятельность производились на территории близлежащих урочищ, а также по южным склонам горы Майтобе, поскольку выпас скота в ущелье невозможен из-за значительной массы крупных глыб и камней, рассеянных практически по всей его площади.

В июле 2019 г., благодаря энтузиазму и желанию собрать историю края и сделать доступной для общественности, местный житель и журналист-краевед Е.Б. Менянбаев (на основе консультаций с В.В. Сараевым) в нижней части ущелья, в 500 м к западу от р. Узын-Каргалы, в 13 км к юго-западу пос. Каргалы обнаружил крупный скальный блок с развалом каменных конструкций под ним, подходящий под описание, составленное Б.Н. Дублицким в своем заключении. В полевом сезоне 2020 г. (июль-август) авторами в составе Каратауского научного отряда Инсти- 
Горячев А.А., Сараев В.В., Егорова Т.А., Чернов М.А. Новые материалы древнего ...

тута археологии им. А.Х. Маргулана произведено обследование данного объекта, получившего предварительное название «Каргалинский камень» (рис. 7, 4).

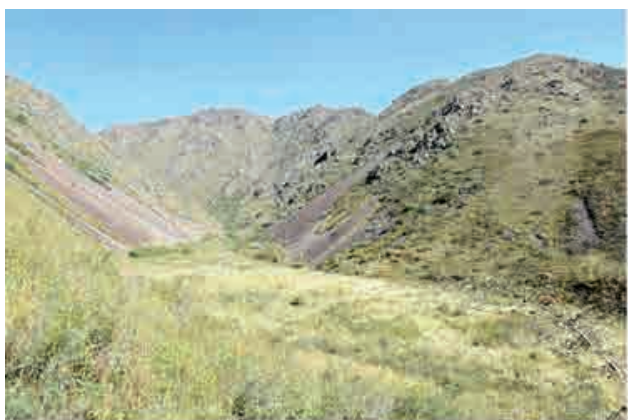

1

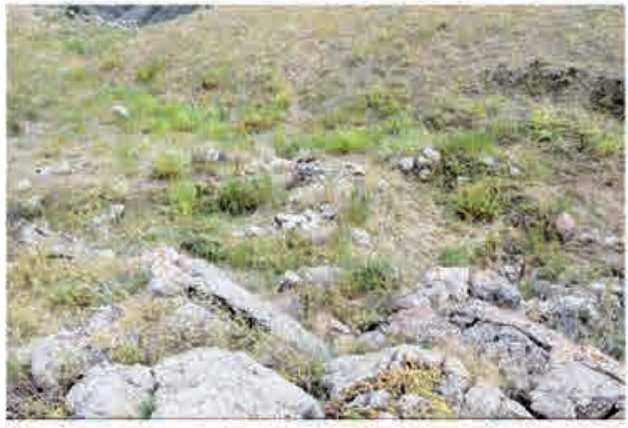

3
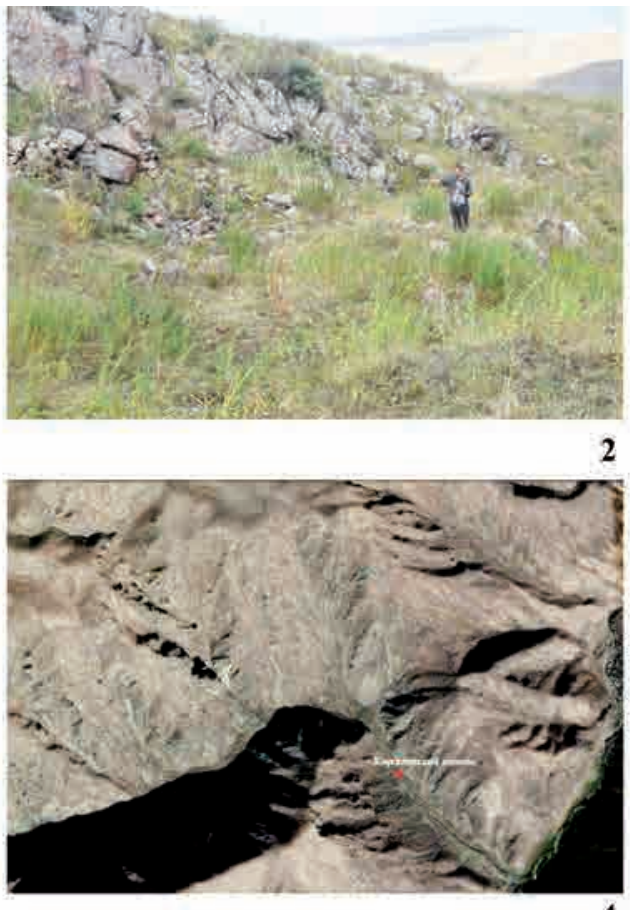

4
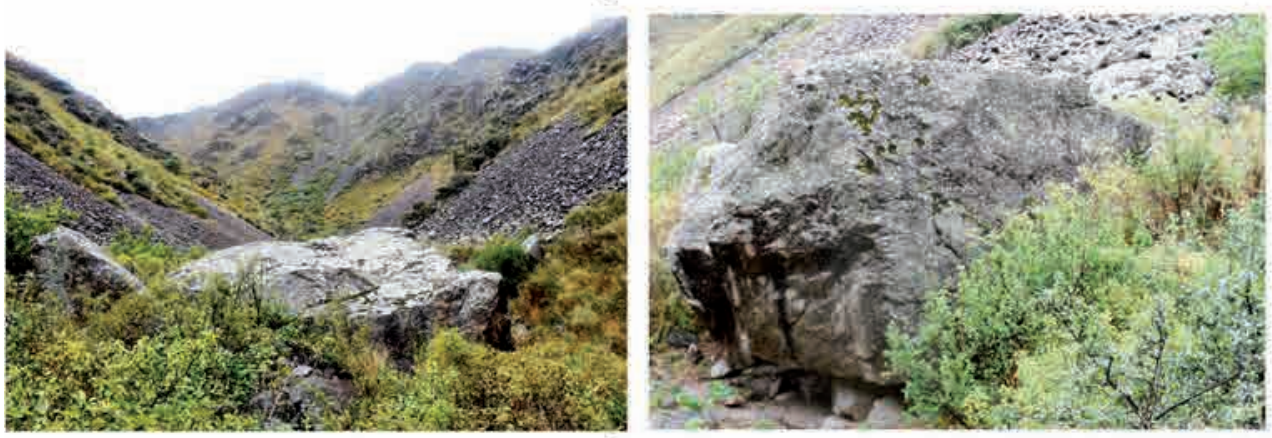

5

Рис. 7. Археологические памятники раннего железного века ущелья Ерменсай:

1 - вид на запад устья ущелья; 2 - поселение Ерменсай-III, вид на северо-восток; 3 - поселение Ерменсай-V, вид на юго-восток; 4 -местоположение Каргалинского камня в ущелье на космоснимке; 5 - Каргалинский камень, вид на запад;

6 - Каргалинский камень, вид на юго-восток (фото: 1 - Горячев А.А.; 2, 3 - Филиппенко С.С.; 5, 6-Егорова Т.А.)

Fig. 7. Archeological monuments of the Early Iron Age in the Ermensay gorge: 1 -west view of the gorge mouth; 2 - Ermensay-III settlement, north-east view; 3 -Ermensay-V settlement, south-east view; 4 - Kargaly rock location in the gorge on the satellite image; 5 -Kargaly rock, west view; 6-Kargaly rock, south-east view (photo: 1 -Goryachev A.; 2, 3-Filippenko S.; 5, 6-Egorova T.) 
го ручья (рис. 7, 5, 6). Упавшая, вероятно, вследствие землетрясения, она остановилась на дне ущелья, опираясь на крупные камни, образовала нишу - своеобразный грот (собственно по геологической терминологии гротом его назвать нельзя - это очевидно не карстовое образование). Данная ниша между двумя опорными скальными блоками, представляет собой «щель», ориентированную по оси СВ-Ю3, размерами $\sim 8$ м в длину, 2-2,5 м в ширину и 50-77 см в высоту. В ней видны остатки каменных перегородок, в средней части между которыми видны следы старых перекопов грунта. Зафиксированы полуразрушенные каменные стенки по всему периметру Каргалинского камня (с южной стороны по берегу - каменная наброска, перекрывавшая щель между скальным блоком и почвой). Перед ним с северной стороны отмечена выровненная площадка между крупными скальными валунами, полукругом примыкавшими к объекту.

Данные признаки совокупно с выявленными артефактами послужили основанием предполагать, что именно этот археологический объект является тем самым местом, где в 1939 г. был найден так называемый «Каргалинский клад». В результате некомпетентного вмешательства лицами, обнаружившими объект, захоронение в центральной части было выкопано. Кости скелета предположительно погребены заново вне могилы. Каменные конструкции с восточной стороны разворочены. Следует допустить, что камни, лежащие перед входом в нишу, составляли некогда кладку, закрывавшую этот вход, впоследствии разрушенную. В ходе последних исследований установлено, что среди местного населения этот объект получил название «Каратас» и неоднократно перекапывался. В различных частях пространства под камнем и на площадке перед ним обнаружены монеты 1948, 1953 и 1961 гг., а также вилка, чайник, упаковка от рыбных консерв, полиэтиленовый пакет из-под молока и спичечная этикетка, которые имели маркировки начала 1970-х гг. Под ним и вблизи найдены лом и нож, подобные тем, что производились в кузнечной мастерской суконного комбината пос. Фабричный до середины 1970-х гг.

На археологическом объекте произведены полные обмеры комплекса и рекогносцировочные раскопки. По внешним данным Каргалинский камень представляет собой скальный блок пятиугольной формы со следующими параметрами: северная сторона ориентирована по оси 3-В - 6,2 м (высота - 4,6 м), восточная сторона ориентирована по оси Ю3-СВ - 5,87 м (высота - 3,1 м), южная сторона ориентирована по оси ЮВ-С3 - 2,80 м (высота - 2,1 м), западная сторона ориентирована по оси Ю3-СВ и Ю-С - 7 м и 5,7 м (высота - 3,6 м). Скальный блок опирается на два крупных валуна у северного края примерно посередине с небольшим смещением к востоку, что привело к образованию ниши (рис. 8, 1). Параметры ее у входа по северной стороне 4,7 м, h (3) - 73 см; h (В) - 57 см и по восточной стороне 3,5 м, h (Ю) 75 см; h (C) - 1,3 м. Параметры общего пространства под камнем: по оси 3-В по центру $-5,8$ м (h - 35-85 cм); по оси $\mathrm{C}-$ Ю по центру - 3,8 м (h $-75 \mathrm{~cm})$; с западного края $-5,7$ м (h $-35 \mathrm{~cm})$, по внутренней стороне ниши 7 м по оси CB-Ю3 (h-23-77 cм). Параметры скального валуна, составившего опору Каргалинского камня - 86 см 
Горячев А.А., Сараев В.В., Егорова Т.А., Чернов М.А. Новые материалы древнего ...
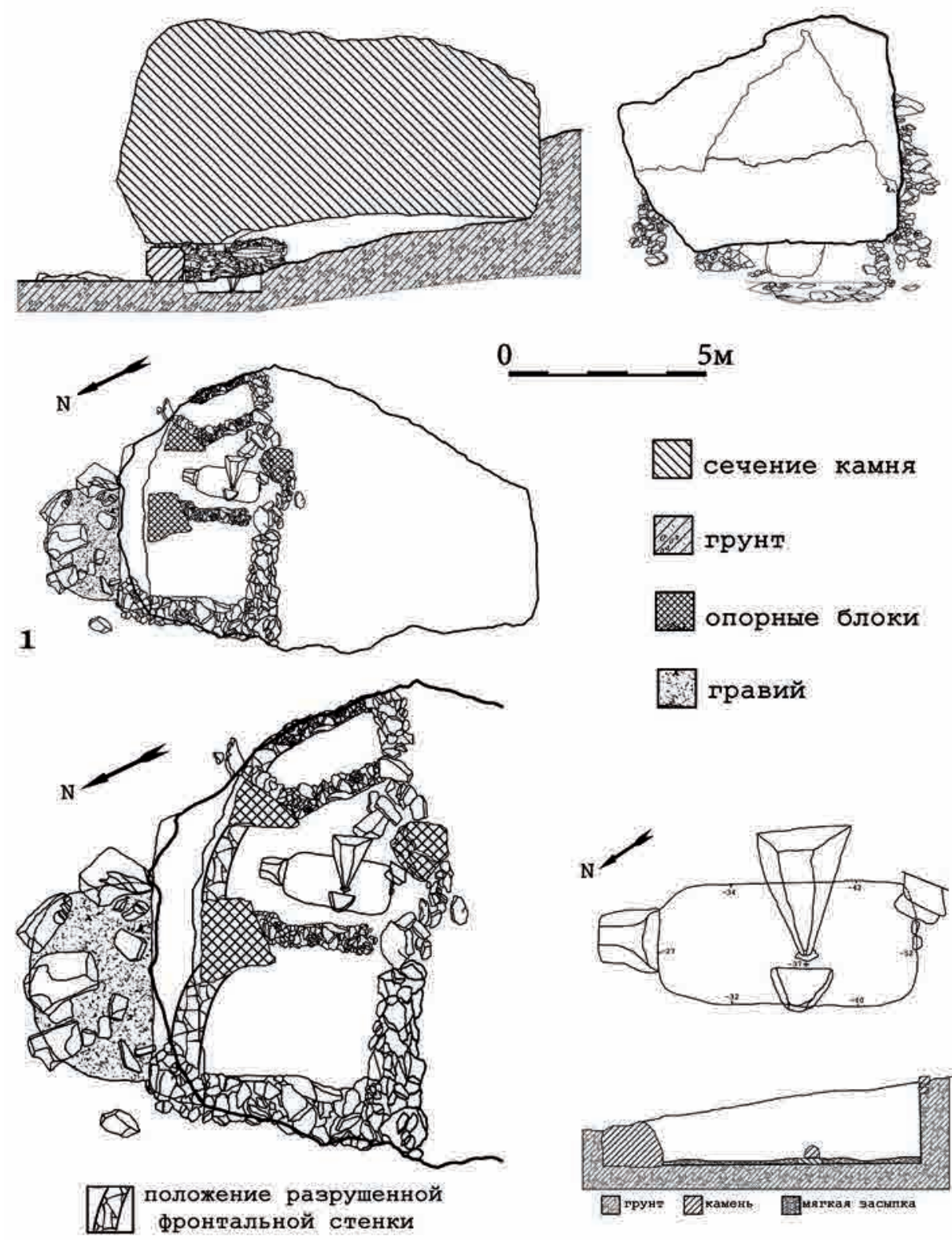

2

$5 \mathrm{M}$

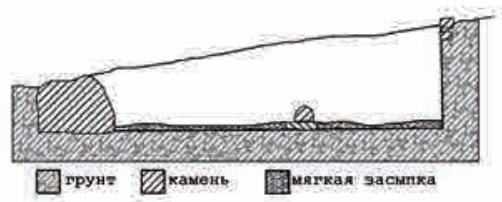

$\mathbf{3}$

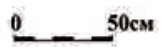

Рис. 8. Реконструкиия погребально-поминальных конструкиий под Каргалинским камнем «Каратас»: 1 - графические проекиии внешнего вида; 2 - ритуальная площадка и устройство погребальной камеры;

3 - план и разрез могильной ямы (графика: 1, 2 - Чернов М.А.; 3 - Горячев А.А.)

Fig. 8. Reconstruction of the burial and memorial structures under the Kargaly stone "Karatas": 1 - graphic projections of the facade of the Kargaly stone; 2 - ritual site and the device of the burial chamber; 3 -plan and section of the burial pit

(graphics: 1, 2 - Chernov M.; 3 - Goryachev A.) 
$($ ЮB-C3 $) \times 105 \quad$ см $\quad($ Ю3-CB $) \times 110$ м $(\mathrm{CB}-\mathrm{Ю}) \times 140$ см (ЮВ-С3). Перед скальным блоком была организована выровненная площадка полукруглой формы размерами 4,8×3,6 м (рис. 8,2 ). По периметру площадки просматриваются выходы крупных скальных валунов берегового основания устья ручья, а пространство между ними заполнено землей и щебнем, среди которых, помимо следов современного посещения комплекса, обнаружены два фрагмента обгорелого дерева с выровненными сторонами с одного края.

Внутри под скальным блоком зафиксированы следы двух каменных выкладок в восточной и западной части ниши, которые условно разделяли все подкаменное пространство на три сектора. В высоту они поднимались от поверхности почвы до нижней плоскости лежащего сверху скального блока. Центральная часть между каменными кладками составляла погребальную камеру подовальной формы, сложенную из камней и валунов и скрепленную глинистым раствором. Западная стенка погребальной камеры начиналась от основного опорного камня в северной части Каргалинского камня. Кладка и верхняя часть опорного блока скреплены между собой глинистым раствором. С южной стороны кладка продолжена вплоть до другого крупного скального блока, на котором он держался по центру. К данной опоре с восточной стороны примыкала группа из двух валунов крупных размеров, не служивших подпорками и не имевших контакта с нижней плоскостью скального блока. От восточного края этих валунов в северном направлении выстроена восточная стенка, наиболее сильно разрушенная в результате ограблений 1930-1970-х гг. Эта клад- ка упиралась в восточный опорный крупный валун в северной части Каргалинского камня. Созданная таким образом погребальная камера составляла в длину по оси Ю3-СВ - 275 см и ширину в Ю3 части -230 см, а в СВ - 180 см (рис. 8, 2).

Вдоль северо-западной стенки конструкции устроена могильная яма размерами $170 \times 80 \mathrm{~cm}$, ориентированная по оси Ю3-СВ. Ее смещение связано с тем, что по центру и восточную часть погребальной камеры занимал крупный валун, нижняя часть которого доходила до дна могилы (рис. 8, 3). Несмотря на неоднократные перекопы удалось установить, что сверху могила перекрывалась настилом из переплетенных ветвей кустарника и тростниковой соломы (своеобразный мат). Настил прослеживается на 10-15 см за пределами могильной ямы (до северо-западной стенки). За пределами настила в юго-западной части погребальной камеры отмечены сухие стебли хвощевой эфедры (определение С.А. Нигматовой). Стенки и дно могильной ямы обмазаны глинистым раствором. Дно могильной ямы ( $\mathrm{CB}-27$ см, Ю3 - 52 см) в толщину до 5 см выстлано слоем ветвей эфедры. В ходе расчистки внутри могильной ямы обнаружены изделия из металла желтого цвета - круглая выпуклая бляшка крупных размеров (14,5 мм) и тонкая плоская пластинка (25 мм).

Справа от погребальной камеры до западного края скального блока образовался сектор ниши: по северной стороне - 160 см, западной -310 см; южной (по оси Ю3-СВ) - 205 см, восточной - 135 см. Его заполнение - кладка из крупных камней и плит, укреплявших снаружи стенки погребальной камеры, которая сооружалась на глиняной основе и, вероятно, пре- 
Горячев А.А., Сараев В.В., Еzорова Т.А., Чернов М.А. Новые материалы древнего ...

дотвращала проникновение осадков в центральную часть. По западному борту ниши между землей и скальным блоком обнаружены остатки каменной кладки. Восточную стенку сектора составил валун, на который опирается Каргалинский камень. Здесь, помимо следов «грабителей» (нож), отмечены кости грызунов, мелкого рогатого скота и зубы лошади.

Левый (восточный) сектор ниши образовался межу внешней выкладкой по краю камня и восточной стенкой погребальной камеры. Его параметры - с северной стороны 145 см, восточной - 350 см; западной - 330 см; южной - 130 см. Зафиксирована каменная кладка на глинянной основе в глубину до 50 см, которая, вероятно, также играла роль внешней обкладки погребальной камеры, но была особенно сильно разрушена по центру и с северной стороны. Часть конструкций стенок найдена за пределами камня, а часть составляла заполнение верхнего слоя сектора. Вокруг одного из них обнаружено 11 золотых округлых нашивных бляшек разных диаметров (от 7,4 мм до 14,5 мм) и три фрагмента золотой фольги в мятом состоянии. Все изделия имеют вмятины и иные механические повреждения. Вероятно, они были утеряны «кладоискателями» во время изъятия вещей из погребения, поскольку именно с этого края камня имеется удобное пространство, где могут свободно поместиться 3-4 человека, оставаясь под прикрытием нависающего камня.

Вещевой материал, обнаруженный под Каргалинским камнем, представлен золотыми предметами в количестве 16 штук, которые типологически можно разделить на две группы (рис. 9). Первая - круглые и выпуклые, и вторая - плоские, неопределённой формы. Все изделия: и сегментарно

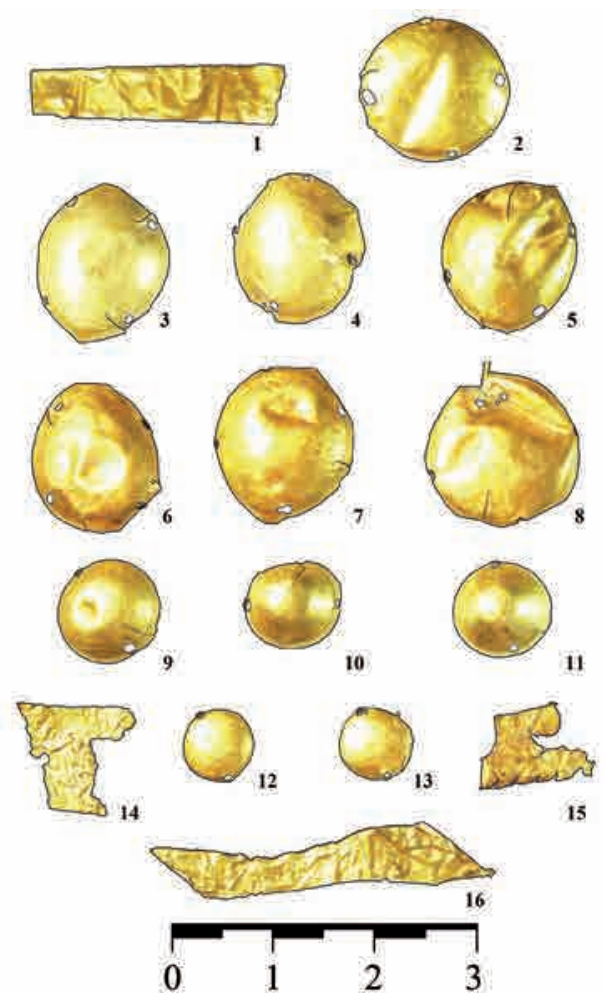

Рис. 9. Золотье изделия из раскопа 2020 г. под Каргалинским камнем: 1, 2 - бляика и пластина из перекопа погребения; 3-16 - бляшки и пластинь из каменного завала в восточной части комплекса (фото и графика - Чернов М.А.)

Fig. 9. Gold items from the excavation of 2020 under the Kargaly stone: 1, 2-plaque and plate from the recess of the burial; 3-16-plaques and plates from the stone burial in the eastern part of the complex (photo and graphics Chernov M.)

сферические бляшки, и декоративные пластинки выполнены из листового металла, толщина которого колеблется в пределах от 0,1 мм до 0,13 мм. Такая толщина была достигнута посредством предварительной проковки листовой заготовки, с последующим вытягиванием на гладкой и жёсткой поверхности при помощи утюжковлощил. При большом увеличении на поверхности изделий видны сохранившиеся разнонаправленные микробороздки и царапины. 


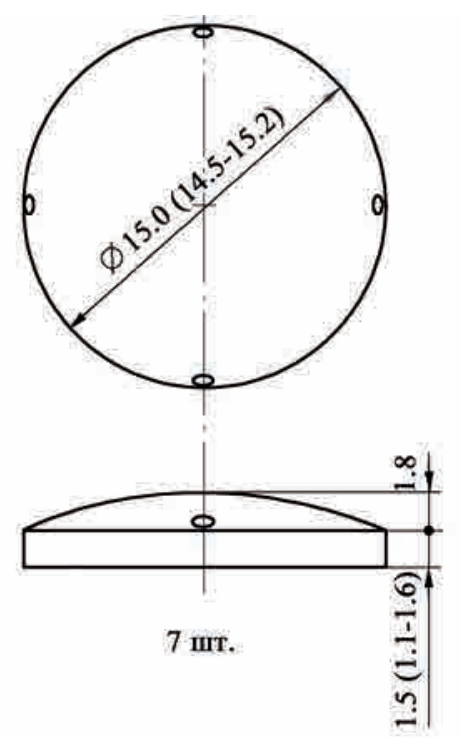

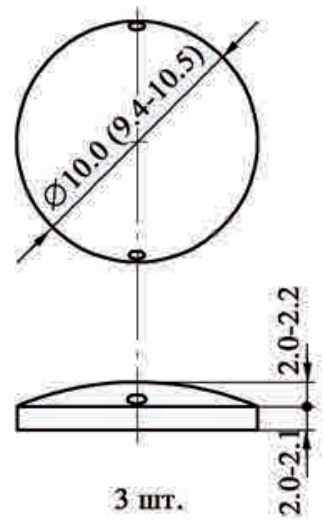

3 шт.

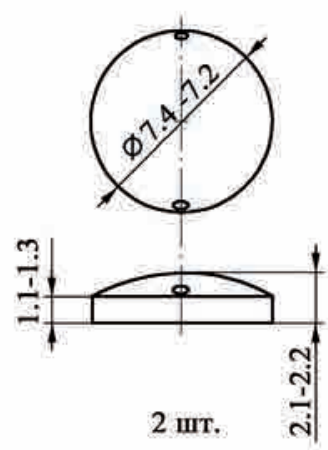

Рис. 10. Типология каргалинских бляшек по размерам (графика - Чернов М.А.)

Fig. 10. Typology of plaques from Kargaly in size (graphic of Chernov M.)

Круглые нашивные бляшки (рис. 9, 2-13) не полусферической, а сегментарно-сферической формы, т.е. их выпуклость имеет высоту меньше радиуса образующей сферы, а плоскость основания не проходит через центр собственно этой сферы. Бляшки подразделяются по размерам (рис. 10). Основным группирующим фактором является их диаметр. По этому признаку их можно подразделить на три группы: крупные диаметром 14,5 мм - 7 экз.; средние (9,5-10,5 мм) - 3 экз.; малые (7,4 мм) - 2 экз. Единство формы, размеров и технологических признаков говорит о том, что все изделия матричного производства, а разница в диаметрах указывает на количество матричных форм.

Если предположить, что эти изделия использовались для украшения костюма погребенного, то становится очевидным группирование и по способу фиксации на элементах костюма. Круглые и выпуклые бляшки (12) име- ют по краям отверстия и, безусловно, пришивались к ткани, либо к коже. Плоские пластины (4) не имеют отверстий и предположительно использовались для плакирования.

Все бляшки выполнены по единому технологическому принципу, сходному с басманным тиснением, возможно с применением пуансона (рис. 11). Срезывание облоя (избыточного металла по краям) производилось остро заточенным ножом. Все бляшки имеют кроме выпуклой поверхности боковую стенку, различной высоты для разных диаметров бляшек соответственно: 2 мм; 1,5 мм; 1,3 мм и 1,1 мм и идущую вертикально к основанию. Отверстия под иглу по бокам бляшек делались непосредственно перед нашиванием их на костюм. Данная операция производилась металлическим шилом на плотной, но проницаемой для шила подложке. Возникшие по краям отверстий заусенцы довольно высокие, и потому 
Горячев А.А., Сараев В.В., Егорова Т.А., Чернов М.А. Новые материалы древнего ...

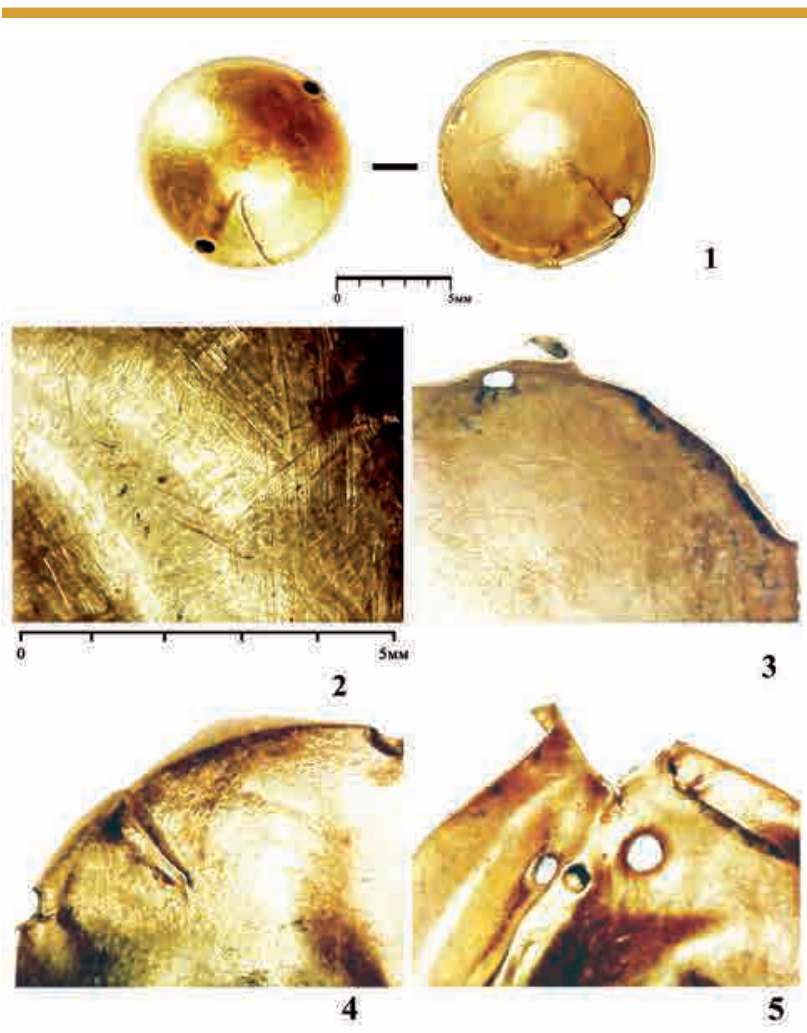

Рис. 11. Детали производства и повреждений каргалинских золотых бляшек (фото Чернов М.)

Fig. 11. Details of production and damage of the Kargaly gold plaques (photo Chernov M.)
Плоские изделия в количестве 4 экз. (рис. 9, 1, 14-16), обнаруженные на месте исследования, несмотря на деформированность поверхности, сохранили конструктивный элемент, позволяющий выделить лицевую и тыльную стороны. Им является прогиб края пластины со стороны реза. У всех пластин имеются края заданной формы наряду с краями случайной конфигурации, образовавшимися в результате разлома или разрыва металла. Они получены при раскрое листа металлической фольги на плотной, но не твердой подложке по определенному замыслу рисунка. В этом качестве могли использоваться древесина, либо кожа крупных животных. Камень, металл, войлок исключаются.

Пластины имеют различную

что они не удалялись и не обрабатывались в мастерской ювелира-торевта, можно предположить, что работы по украшению костюма производились в сжатые сроки и без расчета на ношение, иначе острые неровные края заусенец способствовали бы быстрому износу нитей в условиях бытового пользования. По внешним данным (метрические параметры и технологические признаки), обнаруженные бляшки являются идентичными тем, что входят в состав Каргалинского клада. Более того, аналоги этим изделиям можно выделить в материалах комплекса Чирик-рабат в Приаралье, датируемого III-I вв. до н.э. [Археология Казахстана, 2006, с. 61]. линию силуэта от простой прямой до сложной резной. Края ровные плоские, исключение могут составить только случайные загибы. Следов рачивания краёв с целью крепления к основе не наблюдается. Также на пластинах не имеется отверстий, указывающих на возможное их пришивание к основе. Таким образом, методом исключения можно предположить как способ крепления пластин к основе - приклеивание по типу аппликации [Грязнов, 1958, рис. 47]. Такой способ плакирования возможен не только на металлическую или деревянную основу. Посредством животного клея преднамеренного загибания/подво- 
или клея на основе смол органического или минерального происхождения металлическая фольга малыми элементами могла быть наклеена/нанесена на кожаные пластины. Последние, в свою очередь, могли быть присоединены различными способами (шитьё, скобы, гвозди) на матерчатую или более жесткую (дерево) основу. Известны находки в Пазырыкском комплексе предметов из войлока (седельная подушка) с сохранившимися на них фрагментами серебряной/оловянной фольги [Завитухина, 1977, с. 33].

Закреплённые на коже посредством клея небольшие детали декора вполне способны, без ущерба для целостности, выдержать некоторые деформационные нагрузки, тем более что с уменьшением размера детали из фольги снижается и коэффициент напряжения, возникающего при некотором изгибе основы из кожи, ткани или нетканого материала. Большой удачей можно было бы считать обнаружение следов клеящего вещества на пластинах фольги. Но длительный срок нахождения объектов, практически в экстремальных условиях, вряд ли оставил шансы на сохранность органических соединений, особенно животного происхождения. Бактерии и другие микроорганизмы, вероятно, полностью уничтожили эти следы.

Как всякое украшение, пластины из фольги представляли некий образ (рис. 12). Первая пластина подпрямоугольной формы, длиной 25 мм и шириной на концах 4,5 и 6,0 мм. Широкий конец данной полоски имеет характерную линию обрыва, остальные три имеют край, описанный выше. Следовательно, узкий - был окончанием полоски, и вся пластина могла быть конечностью некоего копытного животного (рис. 12, 1a, 1б). Подобно- го типа конечности можно наблюдать у фигур оленей из листов золотой фольги из Кобяковского кургана [Гугуев, 1992, с. 116-129].

Вторая удлинённая пластина длиной 34 мм и шириной на концах 5,5 и 4,3 мм имеет сложную форму, но в упрощенном виде близка к форме вытянутого параллелограмма. Плавные изгибы краев по длине создают подобие вытянутой шеи птицы из рода гусиных. Окончание этой пластины с более узкой стороны напоминает стилизованную голову птицы упомянутого рода (рис. $12,2 a-2$ ). Из четырех имеющихся пластин эта имеет обрезные края со всех сторон, что говорит о завершенности её формы. И если она не несет в себе целостного образа, то могла бы быть его деталью в случае составного мозаичного решения. Надо отметить, что узкий/острый угол со стороны более широкого конца этого условного параллелограмма подвергся дополнительному подгибанию краёв, что возможно только при подгонке детали под заданные параметры. Как вариант - эта пластина своей формой могла бы отвечать и элементу растительного образа.

Третий фрагмент пластины самый маленький, но и самый интересный по форме. Пластина длиной 11 мм и шириной 7 мм имеет ещё одну сторону с ровным краем обрезки длиной 6 мм и параллельную большой стороне. Это делает общую конфигурацию пластины близкой к форме трапеции. Несмотря на малый размер, на этой пластине отслеживается наибольшее количество декоративных элементов. Широкая сторона условной трапеции украшена пилообразной прорезкой. Зубцы этой прорезки изящно и плавно изогнуты в едином ритме и напоминают стилизованное изображение 


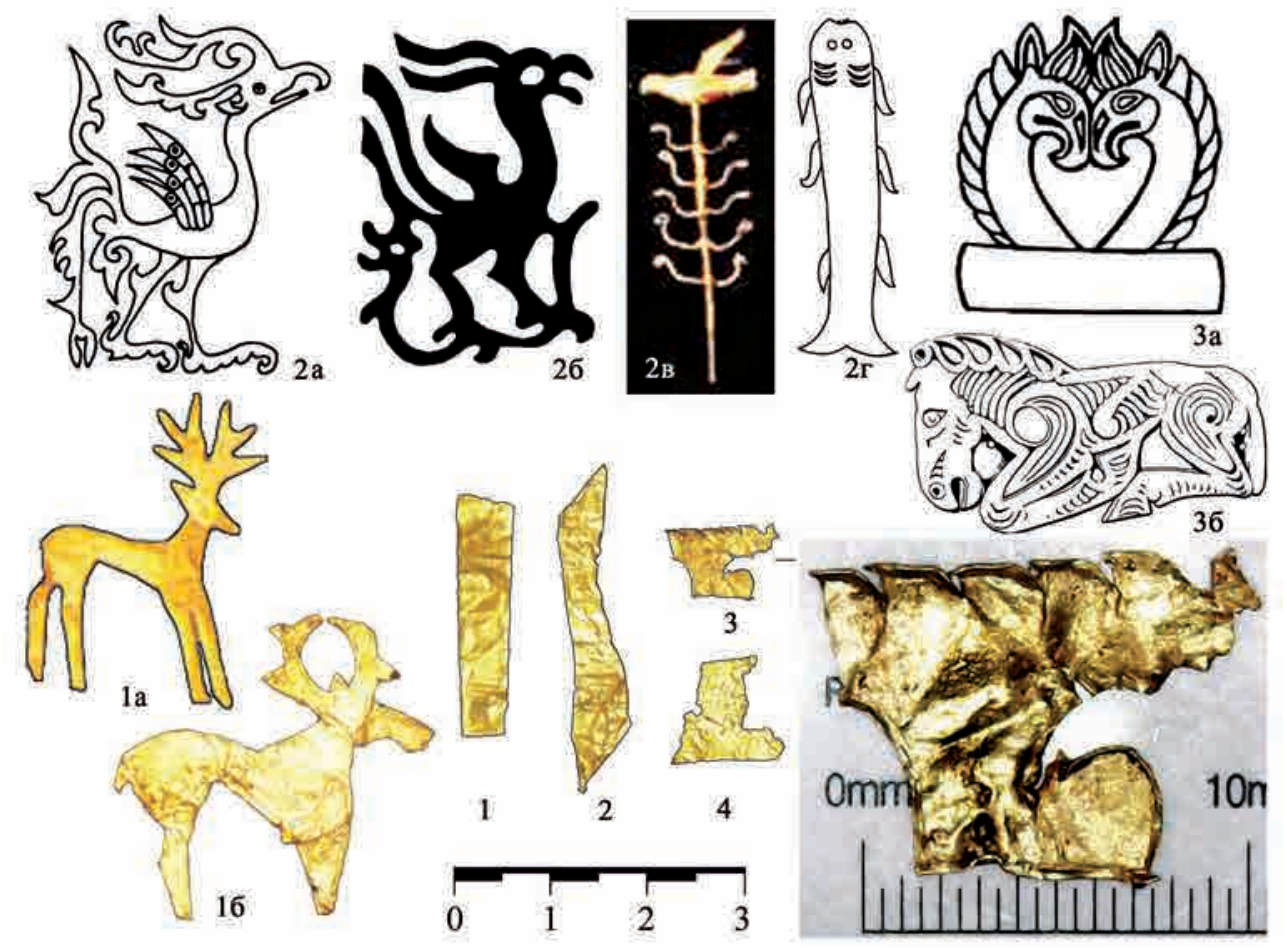

Рис. 12. Возможное функииональное применение золотых пластин:

1-4 - золотье пластины из фольги Каргалинского камня; 1а - Кобяковский курган (по: [Гугуев, 1992]); 1б-курган у станищьь Усть-Лабинской (по: [Засецкая, 1975]);

2a-Пазырык (по: [Артамонов, 1973; Полосьмак, 1994]); 2б-бронзовый китайский сосуд (по: [Полосьмак, 1994]); 2в-курган Иссык (по: [Акишев К.А., 1978]);

$2 z$-Аржан, курган 2 (по: [Руденко, 1953]); 3а-Ак-Алаха (по: [Полосьмак, 1994]); $3 б$ - Сагльь-Бажи, курган № 13 (по: [Грач, 1980])

Fig. 12. The possible functional use of the Kargaly Rock gold plates:

1-4 - gold plates from the Kargaly Rock foil; 1 a - the Kobyakov barrow (by: [Guguev,

1992]); 16 - the barrow near the Ust-Labinsk station (by: [Zasetskaya, 1975]);

2a-Pazyryk (by: [Artamonov, 1973; Polosmak, 1994]);

$2 b$ - Chinese bronze vessel (by: [Polosmak, 1994]);

2c-Issyk barrow (by: [Akishev K.A., 1978]); 2 -Arzhan, barrow 2 (by: Rudenko, 1953]); 3a-Ak-Alakha (by: [Polosmak, 1994]); 3b-Sagly-Bazhy, barrow № 13 (by: [Grach, 1980])

гривы животного. Всего таких зубцов на протяжении 11 мм разместилось шесть, из них пять в хорошем состоянии, и только один крайний сохранился фрагментарно. Сторона длиной 6 мм имеет обрезной прямой край, от концов которого, под углом близким к $90^{\circ}$, идут дугообразные линии прорезки, напоминающие орнаментальные декоративные мотивы (рис. 12, 3a, 3б). На середине ширины пластины дугообразные линии прерываются, и от них идёт линия разрыва/излома до соединения с большей стороной. Таким образом, эта пластинка имеет наименьшую, по отношению к периметру, линию разлома. Тем не менее, завершенного образа не считывается, понятно только то, что это часть большой декоративно разработанной фигуры.

Четвёртый фрагмент - пластина с линейными параметрами $12 \times 10,2$ мм может быть охарактеризо- 
вана как фрагмент параллелограмма, сохранившаяся часть которого имеет два угла (острый и тупой) и край обрыва сложной конфигурации. Эта линия обрыва придала фрагменту форму печатной заглавной латинской буквы «L», у которой верхний и нижний края образованы линией реза. Левая сторона довольно аккуратного слома и только правая образовалась сочетанием линий фигурного реза и бесформенного разрыва. Интерпретация данного фрагмента весьма затруднена невозможностью представить форму декоративных прорезок.

\section{Обсуждение результатов}

Анализируя результаты исследований по Каргалинскому микрорайону, следует отметить, что предгорная зона и устья горных ущелий были задействованы в древности (эпоха бронзы и ранний железный век) земледельцами, которые строили крупные поселения (Кайнар-I, Майбулак-I, Ынтымак-I и II) вплоть до укрепленных (МайбулакII). Так или иначе, все эти поселения, начиная с эпохи бронзы, привязаны к водозаборам древних ирригационных сооружений, и их водоснабжение производилось за счет каналов и арыков, доставлявших воду из родников. В структуре поселений бронзового века насчитывается до 10-12 хозяйственно-жилых подворий, состоявших из жилищ-полуземлянок, хозпостроек и дворов, обозначенных на поверхности каменными кладками.

В раннем железном веке количество подворий на поселениях становится меньше, но численность самих поселений увеличивается, что свидетельствует об уже более самостоятельном ведении хозяйства отдельными семейно-родовым группами. В это же время, как свидетельствует обнаружение в ущелье Майбулак структуры водяной мельницы, развивается более высокая степень специализации производства продукции земледельческих хозяйств. Территории поселений земледельцев предгорной части сохранили следы разработанной системы оросительных каналов, наиболее крупные из которых (КаргалыУзынагаш и Каргалы-Касымбек) достигали свыше 15 км в длину. Здесь же к поселениям раннего железного века примыкают и такие крупные ирригационные сооружения, как акведуки (Касымбек и Ушконыр), что позволяло расширять посевные площади на расстояние в 20-25 км от северных склонов Иле Алатау.

Жители горных ущелий занимались полукочевым скотоводством, устраивая дома-зимовки в устье, а летом выпасая скот на высокогорных плато и в широкой части ущелий у истоков р. Узын-Каргалы и ее притоков. Границей между хозяйствующими субъектами ущелий служили водозаборы каналов и поливных арыков, обычно для данного микрорайона в 1-1,5 км вглубь ущелий. Семейнородовые стоянки древних скотоводов устраивали на склонах с южной экспозицией, часто на площадках близ отдельных скальных групп. Они состояли, как правило, из 1-2 жилых помещений и хозяйственных построек, площадок-загонов. Характерным признаком скотоводческих подворий в горной зоне является наличие вблизи стоянок сеноставов овально-округлой формы диаметром до 10-12 м. Наиболее крупные жилые комплексы (до 10 подворий) обнаружены в урочище Акбастау и ущелье Жылысай, тяготеющих к транзитным кочевым тропам основного русла р. Узын-Каргалы. 
Именно между этими географическими объектами в ущелье Ерменсай обнаружен Каргалинский камень, где зафиксированы конструкции, имеющие все признаки организованного погребального комплекса, имитирующего курган с каменной обкладкой по периметру и ритуальной площадкой с северной стороны. Древние насельники использовали образовавшееся пространство под каменной плитой в качестве места для захоронения. С этой целью, дабы предотвратить сползание и смещение грунта внутрь, данную конструкцию укрепили обломками камней крупных и мелких размеров по периметру. С восточной стороны выстроили стенку из камней средних размеров, а с северной - вход перекрыли большими скальными блоками, установленными на ребро.

Сама могила, устроенная по центру ниши Каргалинского камня, была оконтурена кладкой из каменных плит, уложенных плашмя и скрепленных глинистым раствором. Пространство по периметру погребальной камеры $(2,75 \times 2,3(1,8)$ м) устлано слоем стеблей эфедры. Могила представляла собой грунтовую яму овальной формы, размерами $1,7 \times 0,8$ м, ориентированную по оси Ю3-СВ, дно которой заполнялось слоем эфедры толщиной около 5 см. Человеческих костных останков в погребении не найдено. Ее глубина в северо-восточной части (25 см) не предполагает, чтобы погребенный в ней человек был уложен головой в данном направлении, как это заявлено в заключении Б.Н. Дублицкого (со слов первооткрывателя А. Назаренко). В этом случае, вероятней всего, умершего(ую) похоронили головой в юго-западном направлении (вглубь ниши). Данное предположение более соответствует культурным традиция населения раннего железного века предгорной и горной зоны Иле Алатау [Агеева, 1961, с. 21-40; Акишев, Кушаев, 1963, с. 249-256; Максимова, 1972, с. 123-138; 1980, с. 114122; Горячев, Мотов, 2018, с. 89; Горячев, 2020, с. 96]. Сверху могильная яма накрывалась циновкой (матом) из стеблей кустарника, обильно произрастающего в ущелье Ерменсай, и тростниковой соломы (заключение С.А. Нигматовой), вероятно, собранной по берегам р. Узын-Каргалы.

Характер могильного сооружения абсолютно необычен для погребальных традиций древних племен северных склонов Иле Алатау и всей Илейской долины. Аналогии ему не известны в исследованных комплекcax не только региона Жетысу, но и всей Центральной Азии. Отдельные элементы в виде грунтовой погребальной камеры с кольцевой каменной обкладкой по периметру соотносятся исследователями (в том числе одним из авторов) с усуньским периодом (II в. до н.э. - II в. н.э.) [Акишев, Кушаев, 1963, табл. ХІ; Байпаков, Воякин, Захаров, 2016, с. 665-666; Горячев, 2020, с. 94-96]. Фактически, каменные конструкции по периметру могилы соответствуют элементам надмогильных конструкций курганов этого времени, в том числе и устройству крупных курганов ближайшего могильника у входа в соседнее ущелье Жылысай.

Уточнить датировку частично позволяет вещевой материал данного комплекса. По форме и следам технологического характера округлые бляшки полностью соответствуют подобным изделиям из набора, составляющего Каргалинскую находку 1939 г. [Культура саков и усуней..., 2011, с. 175-196]. Также по форме, размерам и технологическим призна- 
кам можно выделить аналогии из других археологических комплексов и находок. Так, к примеру, в Приаралье из кургана 2, погребения 1 комплекса Чирик Рабат извлечены подобные изделия, датируемые III-I вв. до н.э. [Археология Казахстана, 2006, с. 61]. Аналогии плоской пластины, напоминающей форму конечности копытного животного, можно увидеть у оленей из Кобяковского кургана, вырезанных из листа золотой фольги, который датируется специалистами I-II вв. н.э. [Гугуев, 1992, с. 116-117]. Исходя из этих данных, наиболее вероятное время сооружения погребального комплекса под Каргалинским камнем может рассматриваться в пределах от рубежа эр до II в. н.э., что согласуется с первичной датировкой А.Н. Бернштама [Бернштам, 1940, с. 30-31].

\section{Bblвoдbl}

Природно-географическая ситуация, климатические и экологические условия способствовали возникновению и долговременному функционированию своеобразной структуры жизнеобеспечения населения эпохи бронзы и раннего железного века у северных склонов Иле Алатау, в том числе и в Каргалинском историкогеографическом микрорайоне. Согласно исследованиям, древние земледельцы проживали отдельными хозяйственными дворами и небольшими поселками на предгорных равнинах, чьи крупные поселения на выходе из горных ущелий представляли собой ремесленно-земледельческие центры, а хозяйственно-жилые подворья долины горной реки составляли их округу. Зоной преимущественного развития скотоводства становится территория от устьев горных ущелий до высокогорных плато в зоне альпий- ских лугов. Хозяйственная структура и природные ресурсы позволяли достаточно успешно развивать ремесла (металлургию, гончарство, ткачество) и домашние промыслы (обработка кож, косторезное дело и т.д.). Взаимодействие древних скотоводов и земледельцев привело к созданию комплексной скотоводческо-земледельческой системы хозяйства, которая позволяла им успешно развиваться при любых природно-климатических изменениях этих исторических периодов.

Исследования древних памятников раннего железного века в горной зоне ущелья Узын-Каргалы привело к открытию крайне интересных и перспективных археологических объектов, таких как стационарные поселения Жылысай-I и II, Акбастау-I и II, серия стоянок в районе горной гряды Майтобе, могильники Ерменсай, Жылысай, Узын-Каргалы и т. д. Их наличие свидетельствует о том, что горная зона использовалась круглогодично, что способствовало активному хозяйственно-культурному развитию региона.

Наиболее ярким памятником этого времени по праву считается «Каргалинский клад», обнаруженный в ущелье Узын-Каргалы в 1939 г. По итогам исследовательских работ было определено истинное место его обнаружения - в 500 м вглубь от входа в боковое ущелье Ерменсай. Данный объект, условно названный «Каргалинский камень», представляет собой уникальный погребальный комплекс, при сооружении которого использован массивный скальный блок как монументальная надмогильная конструкция. Погребальные традиции устройства могилы и ограды по ее периметру, а также вещевой материал, соответствуют традициям курганных 
захоронений усуньского периода раннего железного века в пределах I-II вв. н.э. Неординарность погребального комплекса под Каргалинским камнем, несомненно, требует продолжения этих исследований с целью реконструкции и последующей реставрации этого важного археологического памятника.

Благодарности. Авторы выражают глубокую благодарность группе волонтеров - Е.Б. Менян- баеву, Д. Байсеитову, А.К. Медеуову, T.X. Исхакову и сотрудникам Каратауского научного отряда - В.В. Муратовскому, К.С. Потапову, С.С. Филиппенко, Н.Д. Малахову, которые личным участием и большой организационной помощью помогали в проведении полевых исследований в сложных условиях высокогорной зоны Каргалинского ущелья.

\section{ЛИТЕРАТУРА}

1. Агеева Е.И. К вопросу о типах древних погребений Алма-Атинской области // ТИИАЭ АН КазССР. 1961. Т. ХІІ (Археология). С. 21-40.

2. Акишев К.А. Курган Иссык. Искусство саков Казахстана. М.: «Искусство», 1978. $142 \mathrm{c}$.

3. Акишев К.А., Акишев А.К. Древнее золото Казахстана. Алма-Ата: «Өнер». 1983. $264 \mathrm{c}$.

4. Акишев К.А., Кушаев Г.А. Саки и усуни долины реки Или. Алма-Ата: Изд-во АН КазССР, $1963.310 \mathrm{c}$.

5. Артамонов М.И. Сокровища саков. Сер.: Памятники древнего искусства. М.: «Искусство», 1973. 280 с.

6. Археология Казахстана. Алматы: «Онер», 2006. 256 с.

7. Байпаков К.М., Воякин Д.А., Захаров С.В. Могильник Каратума. Некрополь раннего железного века в Семиречье. Алматы: ТОО «Археологическая экспертиза», 2016. $672 \mathrm{c}$.

8. Бейсенов А.3., Джумабекова Г.С., Базарбаева Г.А. Путь к изучению древностей центра страны: история создания первой археологической экспедиции Казахской Академии наук // Археологическое наследие Центрального Казахстана: изучение и сохранение: сб. научн. ст., посвящ. 70-летию организации ЦКАЭ Академии наук Казахстана / отв. ред. А.З. Бейсенов, В.Г. Ломан. Алматы: НИЦИА «Бегазы-Тасмола», 2017. T. 1. C. 11-64.

9. Бернштам А.Н. Золотая диадема из шаманского погребения на р. Карагалинке // КСИИМК. 1940. Вып. 5. С. 23-31.

10. Бернштам А.Н. Историко-археологические очерки Центрального ТяньШаня и Памиро-Алая / Материалы и исследования по археологии СССР. М.-Л.: АН CCCP, 1952. № $26.346 \mathrm{c}$.

11. Горячев A.А. Древний археологический комплекс верховьев ущелья КишиТурген / отв. ред. Г.С. Джумабекова. Алматы: Институт археологии им. А.Х. Маргулана, 2020. 260 c.

12. Горячев А.А., Мотов Ю.А. Археологический комплекс Бутакты-І. Алматы: KazBookTrade, 2018. $264 \mathrm{c}$.

13. Горячев A.A., Сараев В.В. К вопросу о хозяйственно-культурном развитии древнего населения Алматы // Известия НАН РК. Сер. обществ. и гум. наук. 2015. № 6 (304). C. 5-18.

14. Горячев A.A., Сараев В.В. Поселения раннего железного века на северных склонах Иле Алатау // Археологическое наследие Центрального Казахстана: изучение и сохранение / отв. ред. А.З. Бейсенов, В.Г. Ломан. Алматы: НИЦИА «Бегазы-Тасмола», 2017. T. 2. C. 127-136. 
15. Горячев А.А., Сараев В.В., Потапов С.А. Археологические памятники эпохи бронзы и раннего железного века Жамбылского района Алматинской области // Древности Жетысу. Памятники археологии Жамбылского района. Алматы: TOО «Litera», 2016. C. 19-26.

16. Грач А.Д. Древние кочевники в центре Азии. М.: ГРВЛ, 1980. 256 с.

17. Грязнов М.П. Древнее искусство Алтая. Л.: ГосЭрмитаж, 1958. 96 с.

18. Гугуев B.K. Кобяковский курган (К вопросу о восточных влияниях на культуру сарматов I в. н.э. - начала II в. н.э.) // ВДИ. 1992. № 4. С. 116-129.

19. Дублицкий Б.Н. Хроника археологических разведок и находок на территории Казахской ССР (1928-1938). Заключение по осмотру места залегания костяка человека с золотым инвентарем в долине р. Каргалинки близ Алматинской суконной фабрики. Алма-Ата, 1939. С. 24-25 // Архив Института археологии им. А.Х. Маргулана. Инв. №81a/1977.

20. Ильдеряков Н.Н., Ярыгин С.А. Реконструкция этапов и технологии строительства сакского кургана по материалам исследований в микрорайоне Алатау г. Алматы // Археология Казахстана. 2020. № 3 (9). С. 60-69.

21. Завитухина М.П. Пазырык: древняя самобытная культура алтайских кочевников. // Курьер ЮНЕСКО. Январь, 1977. С. 31-37.

22. Засеикая И.П. Золотые украшения гуннской эпохи: По материалам Особой кладовой Гос. Эрмитажа. Л.: «Аврора», 1975. 80 с.

23. Кузьмина E.E. Дионис у усуней (О семантике каргалинской диадемы) // Центральная Азия: Новые памятники письменности и искусства. М.: Наука, Гл. ред. вост. лит., 1987. С. 158-181.

24. Культура саков и усуней Казахстана в археологических коллекциях Центрального государственного музея Республики Казахстан. Научный каталог. Алматы: Өнер, 2011. 320 с. (на каз., рус., англ.).

25. Максимова А.Г. Курганный могильник в урочище Кызыл-Кайнар // Поиски и раскопки в Казахстане / отв. ред. К.А. Акишев. Алма-Ата: Наука, 1972. С. 123-138.

26. Максимова А.Г. Курганы близ Талгара // Археологические исследования древнего и средневекового Казахстана / отв. ред. К.А. Акишев. Алма-Ата: Наука, 1980. C. $114-122$.

27. Мотов Ю.А. Могильник эпохи бронзы Каргалы-I // ИАС. 2007. Вып. 3. C. $80-87$.

28. Нуржанов А.А., Джумабекова Г.С., Базарбаева Г.А. Новые данные о культуре саков Жетысу: краткие результаты полевых исследований 2020 г. на территории г. Алматы // Археология Казахстана. 2020. № 4 (10). С. 70-95.

29. Нурмуханбетов Б.Н., Трифонов Ю.И. Курганные могильники Шубарат и Молалы (краткая характеристика, культурно-хронологический анализ) // Саки и савроматы Казахских степей: контакт культур. Сб. науч. ст., посвящ. памяти Б. Нурмуханбетова Алматы: Институт археологии им. А.Х. Маргулана, 2016. С. 10-18.

30. Полосьмак Н.В. Стерегущие золото грифы» (ак-алахинские курганы). Новосибирск: «Наука», 1994. 125 с.

31. Руденко С.И. Культура населения Горного Алтая в скифское время. М.-Л.: АН СССР, 1953. 402 c.

32. Самашев 3., Григорьев Ф., Жумабекова Г. Древности Алматы. Алматы: ТОО «Археология», 2005. $184 \mathrm{c.}$

33. Сараев B.B. К вопросу изучения археологических памятников Заилийского Алатау // Археологические исследования в Казахстане. Алма-Ата: КазПИ им. Абая, 1992. C. 104-109.

34. Сараев B.B. Принцип построения оросительных систем в предгорьях древнего Семиречья (К вопросу о земледелии на территории Семиречья в древности) // ИАС. 2007. Вып. 3. С. 120-128. 
35. Сараев В.В. Древние поселения урочища Майбулак // IX Оразбаевские чтения. М-лы междунар. науч.-мет. конф. «Современные методы и подходы в изучении историко-культурного наследия Казахстана и сопредельных стран» (г. Алматы, 2829 апреля 2017 г.). Алматы: «Қазақ университеті», 2017. Т. 1. С. 78-82.

36. Сараев B.B. Каргалинский древний историко-географический микрорайон // ИАС. 2017а. Вып. 5. С. 69-90.

37. Сараев В.В., Кожегулова Ф.Т. О способах обогрева древних землянок в предгорной и горной зоне Илейского Алатау // Археология Казахстана. 2019. № 1 (3). C. 28-42.

38. Сараев В.В., Первых Н.М. Каргалинские камни с чашевидными знаками // ИАС. 2001. Вып. 2. С. 165-170.

39. Свод памятников истории и культуры Республики Казахстан. Алматинская область. Алматы: Агентство «Маматай», 2009. 1320 с.

40. Таймагамбетов Ж.К. Древнейшая стоянка первобытного человека вблизи г. Алматы // Алматы. История тысячелетия. Алматы: «Credo», 2008. Вып. 1. С. 34-40.

41. Чернов М.A. Композиционный строй Каргалинской диадемы. Опыт реконструкции // Сакская культура Сарыарки в контексте изучения этносоциокультурных процессов Степной Евразии: сб. науч. ст., посвящ. памяти археолога К.А. Акишева / отв. ред. А.З. Бейсенов. Алматы: НИЦИА «Бегазы-Тасмола», 2015. С. 376-384.

42. Чернов M.A. К вопросу о семантическом прочтении композиции каргалинской диадемы // Древности Жетысу. Памятники археологии Жамбылского района. Алматы: заповедник-музей «Танбалы», 2016. С. 110-130.

43. Ященко С.A. Золотая пластина из усуньского погребения в гроте ущелья Каргалы // ИАС. 2017. Вып. 5. С. 143-155.

\section{REFERENCES}

1. Ageeva, E. I. 1961. In: Trudy Instituta istorii, arheologii i etnografii Akademii nauk KazSSR (Proceedings of the Institute of History, Archeology and Ethnography of the Academy of Sciences of the Kazakh SSR), XII (Archeology), 21-40 (in Russian).

2. Akishev, K. A. 1978. Kurgan Issyk. Iskusstvo sakov Kazahstana (Kurgan Issyk. Art of Saka of Kazakhstan). Moscow: "Iskusstvo" Publ. (in Russian).

3. Akishev, K. A., Akishev, A. K. 1983. Drevnee zoloto Kazahstana (Ancient gold of Kazakhstan). Alma-Ata: "Oner" Publ. (in Russian).

4. Akishev, K. A., Kushaev, G. A. 1963. Saki i usuni doliny reki Ili (Sakas and Usuns of Ili river valley). Alma-Ata: Academy of Sciences of the Kazakh SSR Publ. (in Russian).

5. Artamonov, M. I. 1973. Sokrovishcha sakov (The treasure of Sakas). Moscow: "Iskusstvo" Publ. (in Russian).

6. Arheologiya Kazahstana (Archaeology of Kazakhstan). 2006. Almaty: "Oner" Publ. (in Russian).

7. Baipakov, K. M., Voyakin, D. A., Zakharov, S. V. 2016. Mogilnik Karatuma. Nekropol rannego zheleznogo veka $v$ Semirechie (Karatuma burial Ground. Necropolis of the Early Iron Age in Semirechye). Almaty: “Arheologicheskaya ekspertiza” LTD (in Russian).

8. Beisenov, A. Z., Jumabekova, G. S., Bazarbayeva, G. A. 2017. In: Beisenov, A. Z., Loman, V. G. (eds.). Arheologicheskoe nasledie Centralnogo Kazahstana (Archaeological Heritage of Central Kazakhstan), 1, 11-64. Almaty: "Begazy-Tasmola" Publ. (in Russian).

9. Bernshtam, A. N. 1940. In: Kratkie soobshcheniya Instituta istorii materialnoy kultury (Brief reports of the Institute for the History of Material Culture), 5, 23-31 (in Russian).

10. Bernshtam, A. N. 1952. Istoriko-arheologicheskie ocherki Centralnogo Tyan-Shanya i Pamiro-Alaya. Materialy i issledovaniya po arheologii SSSR (Historical and archaeological essays of the Central Tien Shan and Pamir-Alai. Materials and Research on Archaeology of the USSR), 26. Moscow-Leningrad: USSR Academy of Sciences (in Russian). 
11. Goryachev, A.A. 2020. Jumabekova, G. S. (ed.). Drevniy arheologicheskiy kompleks verhoviev ushcheliya Kishi-Turgen (Ancient archaeological complex of the headwaters of Kishi-Turgen gorge). Almaty: A.Kh. Margulan Archeology (in Russian).

12. Goryachev, A. A., Motov, Yu. A. 2018. Arheologicheskiy kompleks Butakty-I (The archaeological complex of Butakty-I). Almaty: "KazBookTrade" (in Russian).

13. Goryachev, A. A., Saraev, V. V. 2015. In: Izvestiya NAN RK. Seriya obshchestvennyh $i$ gumanitarnyh nauk (Proceedings of the National Academy of Sciences of the Republic of Kazakhstan. Series of Social Sciences and Humanities), 6 (304), 5-18 (in Russian).

14. Goryachev, A. A., Saraev, V. V. 2017. In: Beisenov, A. Z., Loman, V. G. (eds.). Arheologicheskoe nasledie Centralnogo Kazahstana: izuchenie i sohranenie» (Archaeological Heritage of Central Kazakhstan: study and Preservation), vol. 2. Almaty: "Begazy-Tasmola", 127-136 (in Russian).

15. Goryachev, A. A., Saraev, V. V., Potapov, S. A. 2016. In: Drevnosti Zhetysu. Pamyatniki arheologii Zhambylskogo rajona (Zhetysu Antiquities. Archaeological monuments of Zhambyl district). Almaty: "Litera" LTD, 19-26 (in Russian).

16. Grach, A. D. 1980. Drevnie kochevniki v centre Azii (Ancient nomads in the center of Asia). Moscow: "GRVL" (in Russian).

17. Gryaznov, M. P. 1958. Drevnee iskusstvo Altaya (The ancient art of Altai). Leningrad: State Hermitage (in Russian).

18. Guguev, V. K. 1992. In: Vestnik drevney istorii (Journal of Ancient history), 4, 116-129 (in Russian).

19. Dublickiy, B. N. 1939. In: Archives of A.Kh. Margulan Archeology Institute, №81a/1977 (in Russian).

20. Ilderyakov, N. N., Yarygin, S. A. 2020. In: Kazakhstan Archeology, 3 (9), 60-69 (in Russian).

21. Zavitukhina, M. P. 1977. Kurier YUNESKO (UNESCO Courier), 31-37 (in Russian).

22. Zasetskaya, I. P. 1975. Zolotye ukrasheniya gunnskoy epohi: Po materialam Osoboy kladovoy GosErmitazha (Gold Jewelry of the Hunnish Epoch: On the Materials of the Special Storeroom of the State Hermitage). Leningrad: "Aurora” Publ. (in Russian).

23. Kuzmina, E. E. 1987. In: Centralnaya Aziya: Novye pamyatniki pismennosti $i$ iskusstva (Central Asia: New Monuments of Arts and Writing). Moscow: "Nauka" Publ., 158-181 (in Russian).

24. Kultura sakov i usuney Kazahstana v arheologicheskih kollekciyah Centralnogo gosudarstvennogo muzeya Respubliki Kazahstan. Nauchnyj katalog (The Culture of Saka and Usun tribes of Kazakhstan in archeological collections of the Central State Museum of the Republic of Kazakhstan. Scientific catalog). 2011. Almaty: "Oner” Publ. (in Kazakh, Russian, English).

25. Maksimova, A. G. 1972. In: Akishev, K. A. (ed.). Poiski i raskopki v Kazahstane (Searches and excavations in Kazakhstan). Alma-Ata: "Nauka" Publ., 123-138 (in Russian).

26. Maksimova, A. G. 1980. In: Akishev, K. A. (ed.). Arheologicheskie issledovaniya drevnego i srednevekovogo Kazahstana (Archaeological research of ancient and medieval Kazakhstan). Alma-Ata: "Nauka" Publ., 114-122 (in Russian).

27. Motov, Yu. A. 2007. In: Istoriya i arheologiya Semirechiya (History and archeology of Semirechie), 3, 80-87 (in Russian).

28. Nurzhanov, A. A., Jumabekova, G. S., Bazarbayeva, G. A. 2020. In: Kazakhstan Archeology, 4 (10), 70-95 (in Russian).

29. Nurmukhanbetov, B. N., Trifonov, Yu. I. 2016. In: Saki i savromaty Kazahskih stepey: kontakt kultur (Sakas and Savroumats of the Kazakh Steppes: contact of cultures). Almaty: A.Kh. Margulan Archeology Institute, 10-18 (in Russian).

30. Polosmak, N. V. 1994. "Steregushchie zoloto grify" (ak-alahinskie kurgany) (Griffins guarding the gold (Ak-Alakha burial mounds)). Novosibirsk: "Nauka" Publ. (in Russian). 
Горячев А.А., Сараев В.В., Егорова Т.А., Чернов М.А. Новые материалы древнего ...

31. Rudenko, S. I. 1953. Kultura naseleniya Gornogo Altaya v skifskoe vremya (The culture of the Altai Mountains population in the Scythian Time). Moscow - Leningrad: USSR Academy of Sciences (in Russian).

32. Samashev, Z. Grigoriev, F., Jumabekova, G. 2005. Drevnosti Almaty (Antiquities of Almaty). Almaty: "Archaeology" LTD (in Russian).

33. Saraev, V. V. 1992. In: Arheologicheskie issledovaniya v Kazahstane (Archaeological Research in Kazakhstan). Alma-Ata: Abay Kazakh Pedagogical Institute, 104-109 (in Russian).

34. Saraev, V. V. 2007. In: Istoriya i arheologiya Semirechiya (History and Archaeology of the Semirechie), 3, 120-128 (in Russian).

35. Saraev, V. V. 2017. In: IX Orazbaevskie chteniya ( $9^{\text {th }}$ Orazbayev readings). Almaty: "Kazakh University", 1, 78-82 (in Russian).

36. Saraev, V. V. 2017a. In: Istoriya i arheologiya Semirechiya (History and archaeology of the Semirechye), 5, 69-90 (in Russian). (in Russian).

37. Saraev, V. V., Kozhegulova, F. T. 2019. In: Kazakhstan Archeology, 1 (3), 28-42

38. Saraev, V. V., Pervykh, N. M. 2001. Istoriya i arheologiya Semirechiya (History and archeology of the Semirechie), 2, 165-170 (in Russian).

39. Svod pamyatnikov istorii i kultury Respubliki Kazahstan. Almatinskaya oblast (The code of historical and cultural monuments of the Republic of Kazakhstan. Almaty Region). 2009. Almaty: "Mamatay Agency" Publ. (in Russian).

40. Taimagambetov, Zh. K. 2008. In: Almaty. Istoriya tysyacheletiya (Almaty. The history of millennium), 1. Almaty: "Credo" Publ., 34-40 (in Russian).

41. Chernov, M. A. 2015. In: Beisenov, A. Z. (ed.). Sakskaya kultura Saryarki v kontekste izucheniya etnosociokulturnyh processov Stepnoy Evrazii (The Saka culture of SaryArka in the context of studying ethno-sociocultural processes of Steppe Eurasia). Almaty: "Begazy-Tasmola", 376-384 (in Russian).

42. Chernov, M. A. 2016. In: Drevnosti Zhetysu. Pamyatniki arheologii Zhambylskogo rajona (Zhetysu Antiquities. Archaeological monuments of Zhambyl district). Almaty: reserve-museum "Tanbaly", 110-130 (in Russian).

43. Yatsenko, S. A. 2017. In: Istoriya $i$ arheologiya Semirechiya (History and Archaeology of the Semirechye), 5, 143-155 (in Russian).

\footnotetext{
Мүдделер қақтығысы туралы ақпаратты ашу. Автор мүдделер қақтығысының жоқтығын мәлімдейді. / Раскрытие информации о конфликте интересов. Автор заявляет об отсутствии конфликта интересов. / Disclosure of conflict of interest information. The author claim no conflict of interest.
}

Мақала туралы ақпарат / Информация о статье / Information about the article. Редакцияға түсті / Поступила в редакцию / Entered the editorial office: 31.05.2021.

Рецензенттер мақұлдаған / Одобрено рецензентами / Approved by reviewers: 08.06.2021.

Жариялауға қабылданды / Принята к публикации / Accepted for publication: 12.06.2021. 